Review

\title{
Assessing Commensality in Research
}

\author{
Henrik Scander $1, * \mathbb{C}$, Agneta Yngve ${ }^{2,3}(\mathbb{D})$ and Maria Lennernäs Wiklund ${ }^{4}$ \\ 1 School of Hospitality, Culinary Arts and Meal Science, Örebro University, 71202 Grythyttan, Sweden \\ 2 Department of Nutrition, Dietetics and Food Studies, Uppsala University, 75122 Uppsala, Sweden; \\ agneta.yngve@ikv.uu.se \\ 3 School of Health Sciences, Örebro University, 70281 Örebro, Sweden \\ 4 Department of Public Health and Sports Science, University of Gävle, 80176 Gävle, Sweden; \\ maria.lennernas@hig.se \\ * Correspondence: henrik.scander@oru.se; Tel.: +46-19-302008
}

Citation: Scander, H.; Yngve, A.; Lennernäs Wiklund, M. Assessing Commensality in Research. Int. J. Environ. Res. Public Health 2021, 18 , 2632. https://doi.org/10.3390/ ijerph18052632

Academic Editors: Rhona Hanning and Daniel J. Graham

Received: 13 January 2021

Accepted: 2 March 2021

Published: 5 March 2021

Publisher's Note: MDPI stays neutral with regard to jurisdictional claims in published maps and institutional affiliations.

Copyright: (c) 2021 by the authors. Licensee MDPI, Basel, Switzerland. This article is an open access article distributed under the terms and conditions of the Creative Commons Attribution (CC BY) license (https:// creativecommons.org/licenses/by/ $4.0 /)$.

\begin{abstract}
This scoping review focuses on the assessment of commensality in research and attempts to identify used methods for performing research on commensality. It reflects a multidisciplinary research field and draws on findings from Web of Science Core Collection, up to April 2019. The empirical material consisted of 61 studies, whereof most were qualitative research, and some were of quantitative character, including very few dietary surveys. The findings show nine papers categorized as using quantitative approaches, 52 papers were categorized as qualitative. The results show a wide variety of different ways to try to find and understand how commensality can be understood and identified. There seems to be a shift in the very concept of commensality as well as some variations around the concept. This paper argues the need to further investigate the importance of commensality for health and wellbeing, as well as the need to gather data on health and health-related behaviors, living conditions and sociodemographic data in parallel. The review shows the broadranging areas where commensality is researched, from cultural and historical areas to ethnographic or anthropological areas over to dietary assessment. To complement large dietary surveys with methods of assessing who you are eating with in what environment should be a simple way to further our knowledge on the circumstances of meal intake and the importance of commensality. To add 24-h dietary recall to any study of commensality is another way of identifying the importance of commensality for dietary quality. The use of mixed methods research was encouraged by several authors as a good way forward in the assessment of commensality and its importance.
\end{abstract}

Keywords: eating together; conviviality; gastronomy; meal; food studies; dining; eating practice; multidisciplinary

\section{Introduction}

Researchers that find an interest in commensality research will discover that there is no easily identified common research methodology. A number of studies dealing with family meals or social eating, studied as a background for this scoping review revealed that the overlap of studies using the search term "family meal" or "eating together" with the term "commensality" was often inclusive. A recent meta-analysis of family meals and health showed that there is convincing evidence showing that family meals have an important impact on the future meal frequency and nutritional health of children [1]. The definitions of "family meals" has, however, been shown to be inconsistent and concentrating on number of family meals per week [2]. Furthermore, a systematic review could identify the term "eating together" as being important for metabolic indices for nutritional health [3], even though the number of studies was too small for any sensible detailed analysis to be made.

For the nutritionally interested-data on commensality are almost never gathered in connection with large dietary surveys. In dietary assessment tool portals like the Diet, Anthropometry, Physical Activity (DAPA) Measurement Toolkit from the Medical Research 
Council in the UK, all different types of dietary assessment, subjective and objective methods, are listed for easy access. However, the only reference given to commensality is the following: "Individuals can record the time, location and whether they consumed meals alone or with others for each eating occasion, providing information on eating patterns and the eating environment" [4]. No additional information is available in this otherwise very wellequipped resource. Large studies such as NHANES in the United States [5] have not studied eating together and the latest Swedish dietary surveys [6,7] did not include any angle on commensality, just to mention a few. Commensality seems not to be assessed in dietary surveys performed on population level or representative parts thereof, such as different types of registrations or records of food intake, at least not using the word "commensality." This means that the importance of commensality for a healthy diet cannot easily be studied from already existing data from dietary intake studies. The type of venue where food is eaten is more often recorded than whether eaten alone or accompanied by others.

In sociological or anthropological studies of eating situations, commensality is sometimes more thoroughly discussed and assessed [8]. In this regard, assessment of eating together can be studied for example using observations, interviews, or questionnaires.

A reasonable way forward, for the scholar with an interest in how eating together affects our wellbeing as well as what we eat, with whom, where, and how, would be to try to identify different ways of assessment of commensality. This could possibly lead to a broader understanding of the level of importance of eating together over research boundaries and lead to an increased comparability of studies [9].

The aim of this paper is to make a scoping review of quantitative as well as qualitative methods of studying commensality, in nutritional surveys as well as in surveys of other character, such as cultural, sociological, or anthropological studies. We also wanted to identify in which disciplines papers were published in the area as well as how the number of papers using the term commensality has evolved over time.

\section{Materials and Methods}

A scoping review mapping the body of a specific topic was used to summarize and disseminate relevant literature [10]. This scoping review followed the steps suggested by Arksey and O'Malley [11]: (1) identifying the research question, (2) identifying relevant literature, (3) selecting the studies, (4) charting the data and (5) collating, summarizing, and reporting the results. The research questions were: How has commensality been assessed in research studies? Which disciplines and which affiliations do researchers have who have published papers using the term commensality? Finally, how has the number of papers evolved over time?

\section{Literature Search, Database, and Search Terms}

The database searched was Web of Science Core Collection, up to April 2019. Search term used: commensality. The following criteria had to be met for a study to be included:

1. Published up to April 2019.

2. Published in English.

3. Somehow assessing commensality

4. Describing commensality among humans.

We included 61 studies, whereof most used qualitative research methods and some were of quantitative character, including very few dietary surveys.

In the following, we have gone through the quantitative as well as the qualitative papers in some detail, and we produced a number of tables including all papers, listed under six categories.

\section{Results}

The papers we identified were roughly categorized into quantitative and different categories of qualitative papers, such as observations, interviews, and field studies. 


\subsection{Quantitative Research Studies}

Nine papers (Table 1) [12-20] were identified, which used quantitative approaches of some sort to assess commensality, sometimes in combination with qualitative methods and common dietary survey methodology. One paper described a new questionnaire, Well-Being related to Food Questionnaire (Well-BFQ), which is waiting to be validated [14]. Most of the studies using questionnaires were cross-sectional studies [12,13,15-19], some of them performed at two different time points, describing development over time [12,15]. One study looked at only breakfast habits [13]. Two of the papers described the same data $[15,16]$. Finally, two studies, described in three papers, were using a common dietary survey technique (24-h recall) to collect high-quality data of actual intake rather than "usual" intake $[15,16,19]$.

Table 1. Quantitative studies: Summary of the reviewed studies $(n=9)$.

\begin{tabular}{|c|c|c|c|c|}
\hline $\begin{array}{l}\text { Authors (Year), } \\
\text { Country }\end{array}$ & Objectives & $\begin{array}{c}\text { Methods, Settings and } \\
\text { Participants }\end{array}$ & Results/Discussions & $\begin{array}{c}\text { Results in Relation to } \\
\text { Review }\end{array}$ \\
\hline $\begin{array}{l}\text { De Backer, CJS, } \\
\text { (2013) [12] } \\
\text { Belgium }\end{array}$ & $\begin{array}{l}\text { To investigate if } \\
\text { reported childhood } \\
\text { food habits predict the } \\
\text { food habits of students. }\end{array}$ & $\begin{array}{l}\text { Cross-sectional survey } \\
\text { of } 104 \text { higher education } \\
\text { students in Belgium. } \\
\text { Convenience sample. }\end{array}$ & $\begin{array}{l}\text { Students appeared to } \\
\text { maintain recalled } \\
\text { childhood food rituals, } \\
\text { mainly the matrilineal } \\
\text { dominance. Breakfast } \\
\text { and dinner patterns } \\
\text { especially influenced } \\
\text { commensality. }\end{array}$ & $\begin{array}{c}\text { Frequencies of recalled } \\
\text { childhood family meals } \\
\text { influenced the frequencies of } \\
\text { current commensality. More } \\
\text { so for breakfasts and dinners } \\
\text { than for lunches. }\end{array}$ \\
\hline
\end{tabular}

\begin{tabular}{cc}
\hline & To investigate \\
Gotthelf SJ, & relationship between \\
bempestti CP. & breakfast, \\
(2017) [13] & sociodemographic \\
Argentina & $\begin{array}{c}\text { outcome measures, and } \\
\text { nutritional status } \\
\text { among school children. }\end{array}$ \\
& To develop and \\
& $\begin{array}{c}\text { validate an instrument } \\
\text { for assessing } \\
\text { Guillemin I, et al. } \\
\text { (2016) [14] France } \\
\end{array}$ \\
& $\begin{array}{c}\text { well-being associated } \\
\text { aith food and eating in } \\
\text { an adult population. }\end{array}$
\end{tabular}

Holm, L et al. (2016) [15] Danmark

To analyze changes in the social organization of eating over time.
283 children $9-13$ years of age, attending schools in the City of Salta, urban and peri-urban areas. Questionnaires, cross-sectional study.
A preliminary with 444 subjects with balanced diet, non-balanced diet and standard diet. Factor analysis. validation was made
Children of lower educated parents were at higher risk of skipping breakfast, which also related to having breakfast alone.
Only breakfast habits assessed, related to nutritional status and socioeconomic status.
The final Well-BFQ was shown to be a unique, modular tool that assesses the full picture of well-being related to food and eating habits.
The questionnaire is not available in English as yet, and a bigger validation study is underway.
Two cross-sectional surveys; in four Nordic countries 1997-2012: individuals 15 and older, $24 \mathrm{~h}$ recall of diet. 1997 4808, 20128248
Some differences were seen between 1997 and 2012, not consistent between countries. More solitary meals and quick meals could be traced over the years. Single households stood out.

Occasional eating out in the Nordic countries. More people ate out in Sweden and Finland compared to the other countries. Often linked to work-life in urban settings.
8248 individuals $15-80$ years, Internet-based survey. The response rate was low, 9-11\%. The lowest educated segment was underrepresented.
(2017) [16]

Danmark relation to work or

leisure activity, related to some factors in people's lives.
The authors strongly recommend the use of a mixed-methods methodology with 24-h recall.

Suggests employing measures that distinguish between eating venues (lowbrow vs highbrow) and kind (restaurant, café), the money spent on eating out and records of physical features of the venue that facilitate communication. 
Table 1. Cont.

\begin{tabular}{|c|c|c|c|c|}
\hline $\begin{array}{l}\text { Authors (Year), } \\
\text { Country }\end{array}$ & Objectives & $\begin{array}{l}\text { Methods, Settings and } \\
\text { Participants }\end{array}$ & Results/Discussions & $\begin{array}{c}\text { Results in Relation to } \\
\text { Review }\end{array}$ \\
\hline $\begin{array}{c}\text { Marquis M, et al. } \\
\text { (2018) [17] } \\
\text { Canada }\end{array}$ & $\begin{array}{c}\text { To explore } \\
\text { environmental, } \\
\text { personal, and } \\
\text { behavioral factors as } \\
\text { determinants of food } \\
\text { behavior. }\end{array}$ & $\begin{array}{c}857 \text { university students } \\
\text { in Quebec, Canada ate, } \\
20 \% \text { alone in apt, } 11 \% \\
\text { shared with a partner } \\
\text { and 5\% lived with } \\
\text { parents }\end{array}$ & $\begin{array}{l}\text { Eater profiles } \\
\text { developed from factor } \\
\text { analysis: the planet- } \\
\text { nutrition-kitchen lover, } \\
\text { the utilitarian } \\
\text { loneleater, the } \\
\text { body-driven eater, and } \\
\text { the mindless eater. }\end{array}$ & $\begin{array}{l}\text { Fairly simple questionnaire } \\
\text { based on a number of } \\
\text { published statements. These } \\
\text { were analyzed in relation to } \\
\text { gender and place of } \\
\text { residence. The authors } \\
\text { suggest further studies of } \\
\text { food insecurity, health, and } \\
\text { differences in resilience. }\end{array}$ \\
\hline $\begin{array}{l}\text { Sobal J, Nelson } \\
\text { MK (2003) [18] } \\
\text { USA }\end{array}$ & $\begin{array}{l}\text { To investigate usual } \\
\text { meal partners in } \\
\text { commensal units and } \\
\text { frequency of eating } \\
\text { with others. }\end{array}$ & $\begin{array}{c}663 \text { adults in a US } \\
\text { community responding } \\
\text { to a mailed } \\
\text { questionnaire. }\end{array}$ & $\begin{array}{c}\text { A useful graphic } \\
\text { presentation of eating } \\
\text { meals alone and eating } \\
\text { with others: } 27 \% \text { ate no } \\
\text { meals alone while } 72 \% \\
\text { rarely ate with others } \\
\text { weekly. }\end{array}$ & $\begin{array}{l}\text { Most questions used are } \\
\text { available in the paper. A } \\
\text { substantial amount of eating } \\
\text { is done alone, more than half } \\
\text { ate breakfast alone but few } \\
\text { ate dinners by themselves. }\end{array}$ \\
\hline $\begin{array}{c}\text { Yates L, Warde A. } \\
\text { (2017) [19] } \\
\text { Great Britain }\end{array}$ & $\begin{array}{l}\text { Investigating aspects of } \\
\text { British meal patterns, } \\
\text { provisioning and } \\
\text { preparation, timings } \\
\text { and commensality. }\end{array}$ & $\begin{array}{l}\text { Sample from a } \\
\text { supermarket consumer } \\
\text { panel. } 2784 \text { individuals, } \\
45 \% \text { response rate. } \\
\text { Older, more affluent, } \\
\text { better educated } \\
\text { respondents and } \\
\text { respondents without } \\
\text { children were } \\
\text { overrepresented. }\end{array}$ & $\begin{array}{l}\text { Household members } \\
\text { are the most common } \\
\text { companions at meals } \\
(75 \%), \text { work colleagues } \\
(16 \%) . \text { Meals later in } \\
\text { the day are more } \\
\text { probably eaten in } \\
\text { companionship. When } \\
\text { singles eat alone they } \\
\text { eat simpler dishes. }\end{array}$ & $\begin{array}{l}\text { The sampling is of utmost } \\
\text { importance for the result. } \\
\text { This type of survey can be } \\
\text { performed to investigate } \\
\text { commensality in a } \\
\text { comprehensive manner, and } \\
\text { in agreement with } \\
\text { suggestions of Holm et al. } \\
\text { Adult-only households were } \\
\text { underrepresented in this } \\
\text { sample. Timing was } \\
\text { included in the analysis. }\end{array}$ \\
\hline $\begin{array}{c}\text { Sato et al. (2015) } \\
\text { [20] } \\
\text { Brazil }\end{array}$ & $\begin{array}{c}\text { Investigated family } \\
\text { meals and explored } \\
\text { associations with } \\
\text { family and } \\
\text { sociodemographic } \\
\text { characteristics, BMI, } \\
\text { and eating practices }\end{array}$ & $\begin{array}{l}\text { A population-based } \\
\text { cross-sectional study, } \\
\text { using complex } \\
\text { cluster-sampling, } \\
\text { conducted in the city of } \\
\text { Santos, Brazil with } 439 \\
\text { mothers. }\end{array}$ & $\begin{array}{l}\text { Family meals were } 54 \% \\
\text { more prevalent among } \\
\text { mothers with high } \\
\text { compared to low } \\
\text { education. Eating no } \\
\text { meals with family was } \\
\text { more prevalent among } \\
\text { those reporting that } \\
\text { eating was one of the } \\
\text { biggest pleasures. }\end{array}$ & $\begin{array}{l}\text { The authors suggest the need } \\
\text { for further research } \\
\text { investigating the effects of } \\
\text { family meals on mothers' } \\
\text { health through nutritional } \\
\text { and phenomenological } \\
\text { approaches. }\end{array}$ \\
\hline
\end{tabular}

A common problem in most studies was that the response rates were low and in some cases clearly skewed, with non-responders of lower education level. Some suggestions that could be read out from the scoping review regarding the use of quantitative methods to assess commensality were recommending the use of mixed methods approaches, applying rigorous sampling techniques, including type of venue in the investigation (lowbrow, highbrow) and whether the venue facilitated commensality or not. Mailed or online questionnaires were used in several studies. Many authors suggested inclusion of with whom, where, how, when, questions. In all studies using questionnaires, socio-demographic characteristics were collected, in a more or less rigorous fashion and of course, ethical approval was sought, with informed consent collected from participants as soon as issues of sensitive nature were collected.

\subsection{Qualitative Research Studies}

Qualitative studies are described as those involving the systematic collection, organization, and interpretation of textual material derived from talk or observation [9]. Qualitative 
studies are used in the exploration of meanings of social phenomena as experienced by individuals themselves, in their natural context [21]. Among the identified papers on commensality assessment, 51 papers were categorized as qualitative. These were put into subcategories, such as qualitative interviews (Table 2) [22-41] and ethnological studies (Table 3) [42-47], log book plus interview (Table 4) [48-51] case studies (Table 5) [52,53] and diverse methods (Table 6) [54-73].

Table 2. Interviews: summary of the reviewed studies $(n=20)$.

\begin{tabular}{|c|c|c|c|c|}
\hline $\begin{array}{l}\text { Authors } \\
\text { (Year), } \\
\text { Country }\end{array}$ & Objectives & $\begin{array}{l}\text { Methods, Settings and } \\
\text { Participants }\end{array}$ & Results/Discussions & Results in Relation to Review \\
\hline $\begin{array}{c}\text { Andersen } \\
\text { et al. (2015) } \\
\text { [22] } \\
\text { Denmark }\end{array}$ & $\begin{array}{l}\text { To broaden our } \\
\text { understanding of the } \\
\text { concept of } \\
\text { commensality by } \\
\text { investigating what it } \\
\text { means to "share a } \\
\text { meal." }\end{array}$ & $\begin{array}{l}\text { Study: a hot meal } \\
\text { based on Nordic } \\
\text { ingredients vs the } \\
\text { normal Danish school } \\
\text { meal arrangement in } \\
\text { which children bring } \\
\text { lunch packs. In-depth } \\
\text { interviews with } \\
\text { teachers, chefs and } \\
\text { staff, focus group } \\
\text { interviews with pupils. }\end{array}$ & $\begin{array}{l}\text { The study showed how } \\
\text { different types of school } \\
\text { meal arrangement } \\
\text { influenced the social life of } \\
\text { a school class, and how } \\
\text { these arrangements } \\
\text { involved strategies of } \\
\text { inclusion and exclusion. }\end{array}$ & $\begin{array}{l}\text { The results fail to confirm the } \\
\text { conventional view that shared } \\
\text { meals have greater social } \\
\text { impacts and benefits than } \\
\text { eating individualized foods. } \\
\text { The article argues that the } \\
\text { social entrepreneurship } \\
\text { involved in sharing individual } \\
\text { lunch packs might even } \\
\text { outweigh some of the benefits } \\
\text { of shared meals where } \\
\text { everyone is served the same } \\
\text { food. }\end{array}$ \\
\hline $\begin{array}{c}\text { Backett- } \\
\text { Milburn } \\
\text { (2010) [23] } \\
\text { UK }\end{array}$ & $\begin{array}{l}\text { To understand more } \\
\text { about the social and } \\
\text { cultural conditions } \\
\text { which might be } \\
\text { promoting more } \\
\text { positive dietary health } \\
\text { and physical } \\
\text { well-being amongst } \\
\text { middle class families }\end{array}$ & $\begin{array}{l}\text { Parents / main food } \\
\text { providers of boys and } \\
\text { girls aged } 13 / 14 \text { years } \\
\text { Eastern Scotland, } \\
\text { Qualitative interviews } \\
\text { in parents' homes. } \\
\text { Topic guide. }\end{array}$ & $\begin{array}{l}\text { Most parents' accounts } \\
\text { appeared rooted in a } \\
\text { taken-for-grantedness that } \\
\text { family members enjoyed } \\
\text { good health, lived in secure } \\
\text { and unthreatening } \\
\text { environments regarding } \\
\text { health and resources, and } \\
\text { able to lead active lives. }\end{array}$ & $\begin{array}{l}\text { Parents described attempts to } \\
\text { achieve family eating practices } \\
\text { such as commensality, cooking } \\
\text { from scratch, and encouraging } \\
\text { a varied and nutritional } \\
\text { "adult" diet and cosmopolitan } \\
\text { tastes, but work and activities } \\
\text { could compromize these }\end{array}$ \\
\hline $\begin{array}{c}\text { Bailey (2017) } \\
\text { [24] } \\
\text { Netherlands }\end{array}$ & $\begin{array}{l}\text { To examine how the } \\
\text { travel of food, food } \\
\text { practices, and } \\
\text { commensality reflect } \\
\text { the flow of norms, } \\
\text { practices, identities, } \\
\text { and social capital } \\
\text { between India and the } \\
\text { Netherlands. }\end{array}$ & $\begin{array}{l}30 \text { in-depth interviews } \\
\text { conducted } \\
\text { among Indian migrants } \\
\text { living in The } \\
\text { Netherlands }\end{array}$ & $\begin{array}{l}\text { The main themes from the } \\
\text { data included food from } \\
\text { home, cooking practices, } \\
\text { food sharing, and family } \\
\text { relationships. Migrants' } \\
\text { sense of belonging was } \\
\text { related to the food they } \\
\text { brought from home and } \\
\text { the memories it generated. }\end{array}$ & $\begin{array}{l}\text { Commensality with co-ethnics } \\
\text { led to a sense of community } \\
\text { and stronger community } \\
\text { bonds. Commensality with } \\
\text { other non-Indian groups was } \\
\text { perceived to be problematic. } \\
\text { The exchanges of food, eating } \\
\text { practices, and care created a } \\
\text { sense of "co-presence" in lives } \\
\text { of migrants. }\end{array}$ \\
\hline $\begin{array}{c}\text { Belon (2016) } \\
\text { [25] } \\
\text { Canada }\end{array}$ & $\begin{array}{l}\text { To identify the barriers } \\
\text { to and opportunities } \\
\text { for healthy eating } \\
\text { among residents of four } \\
\text { communities } \\
\text { representing the } \\
\text { heterogeneity of urban } \\
\text { communities. }\end{array}$ & $\begin{array}{l}\text { A total of } 35 \\
\text { individuals } \\
\text { participated, from four } \\
\text { communities in the } \\
\text { province of Alberta, } \\
\text { representing a } \\
\text { spectrum of urban } \\
\text { communities as defined } \\
\text { by Statistics Canada, } \\
\text { semi-structured } \\
\text { interviews one-on-one } \\
\text { were used. }\end{array}$ & $\begin{array}{l}\text { This study identifies a set } \\
\text { of meta-themes that } \\
\text { summarize and illustrate } \\
\text { the interrelationships } \\
\text { between environmental } \\
\text { attributes, people's } \\
\text { perceptions, and eating } \\
\text { behaviors }\end{array}$ & $\begin{array}{l}\text { This paper recognizes } \\
\text { interrelationships among } \\
\text { multiple environmental factors } \\
\text { that may help efforts to design } \\
\text { effective community-based } \\
\text { interventions and address } \\
\text { knowledge gaps on how } \\
\text { sociocultural, economic, and } \\
\text { political environments } \\
\text { intersect with physical worlds }\end{array}$ \\
\hline
\end{tabular}


Table 2. Cont.

\begin{tabular}{|c|c|c|c|c|}
\hline $\begin{array}{l}\text { Authors } \\
\text { (Year), } \\
\text { Country }\end{array}$ & Objectives & $\begin{array}{l}\text { Methods, Settings and } \\
\text { Participants }\end{array}$ & Results/Discussions & Results in Relation to Review \\
\hline $\begin{array}{c}\text { Cho (2015) } \\
\text { [26] } \\
\text { Korea }\end{array}$ & $\begin{array}{c}\text { To examine } \\
\text { cross-cultural } \\
\text { variations of } \\
\text { perceptions and actual } \\
\text { practices of } \\
\text { commensality and } \\
\text { solo-eating. }\end{array}$ & $\begin{array}{l}\text { University students in } \\
\text { urban Korea and Japan, } \\
\text { survey and } \\
\text { self-administered } \\
\text { questionnaire. }\end{array}$ & $\begin{array}{l}\text { More Korean students } \\
\text { reported they prefer } \\
\text { commensality and tend to } \\
\text { eat more when they eat } \\
\text { commensally. Japanese } \\
\text { reported no preference on } \\
\text { commensality and there } \\
\text { was no notable difference } \\
\text { in food quantities. }\end{array}$ & $\begin{array}{l}\text { The study revealed } \\
\text { cross-cultural variations of } \\
\text { perceptions and practices of } \\
\text { commensality and solo-eating } \\
\text { in non-western settings. Open } \\
\text { ended question questionnaire. }\end{array}$ \\
\hline $\begin{array}{c}\text { Danesi } \\
(2018)[27] \\
\text { Switzerland }\end{array}$ & $\begin{array}{l}\text { To contribute to } \\
\text { research on social and } \\
\text { cultural values of } \\
\text { commensality and on } \\
\text { the contemporary } \\
\text { debate on changes of } \\
\text { eating patterns by } \\
\text { considering European } \\
\text { young people's food } \\
\text { sharing practices }\end{array}$ & $\begin{array}{l}\text { French, German, and } \\
\text { Spanish young adult, } \\
\text { In-depth } \\
\text { semi-structured } \\
\text { interviews and } \\
\text { observations }\end{array}$ & $\begin{array}{l}\text { The different nationalities } \\
\text { contribute to emphasizing } \\
\text { cultural diversity and } \\
\text { laying the foundations for } \\
\text { highlighting poignant } \\
\text { differences between } \\
\text { countries, in relation to } \\
\text { meal times, content, places } \\
\text { of food sociability, social } \\
\text { organization at shared } \\
\text { meals and the role of food } \\
\text { sharing. }\end{array}$ & $\begin{array}{l}\text { These aspects reveal different } \\
\text { social meanings attached to } \\
\text { food and commensality, as } \\
\text { well as variability of } \\
\text { commensal forms between } \\
\text { young people living in or } \\
\text { coming from different } \\
\text { European countries }\end{array}$ \\
\hline $\begin{array}{l}\text { Dodds, } \\
\text { Chamber- } \\
\text { lain (2016) } \\
\text { [28] } \\
\text { New } \\
\text { Zealand }\end{array}$ & $\begin{array}{l}\text { To analyze the content } \\
\text { of a weekly nutrition } \\
\text { column in a popular } \\
\text { New Zealand } \\
\text { magazine, from a social } \\
\text { constructionist } \\
\text { perspective. }\end{array}$ & $\begin{array}{l}\text { New Zealand } \\
\text { magazine text analyses }\end{array}$ & $\begin{array}{l}\text { The articles advocated } \\
\text { eating for health, but } \\
\text { depicted nutritional } \\
\text { information as open to } \\
\text { interpretation. Fear-based } \\
\text { messages were used by } \\
\text { linking "unhealthy" food } \\
\text { choices with fatness and } \\
\text { chronic ill health. }\end{array}$ & $\begin{array}{l}\text { Unhealthy foods were } \\
\text { portrayed as more enjoyable } \\
\text { than healthy foods, social } \\
\text { occasions involving food were } \\
\text { constructed as problematic. }\end{array}$ \\
\hline $\begin{array}{l}\text { Fossgard } \\
(2018)[29] \\
\text { Norway }\end{array}$ & $\begin{array}{l}\text { To study how students } \\
\text { experience and } \\
\text { perceive their packed } \\
\text { lunches and lunch } \\
\text { breaks and to what } \\
\text { extent the lunch break } \\
\text { is a space for children's } \\
\text { sociality and for } \\
\text { teachers' } \\
\text { governmentality? }\end{array}$ & $\begin{array}{l}\text { 11-year-old Students, } \\
165 \text { participants, } \\
\text { focus-group } \\
\text { discussions. }\end{array}$ & $\begin{array}{l}\text { Students expressed that } \\
\text { they appreciated their own } \\
\text { packed lunches since they } \\
\text { could decide what to eat. } \\
\text { Shortage of time and } \\
\text { disturbance in the } \\
\text { classroom could ruin a } \\
\text { good meal. The main issue } \\
\text { raised was with whom } \\
\text { they could sit and eat their } \\
\text { packed lunches. }\end{array}$ & $\begin{array}{l}\text { Findings underline the } \\
\text { importance of considering the } \\
\text { emotional dimensions of } \\
\text { eating and that commensal } \\
\text { eating is not dependent on } \\
\text { sharing the same food. The } \\
\text { children experienced that the } \\
\text { lunch break was governed by } \\
\text { an adult agenda in which they } \\
\text { had limited opportunities to } \\
\text { create their own spaces. }\end{array}$ \\
\hline $\begin{array}{l}\text { Giacoman } \\
\text { (2016) [30] } \\
\text { Chile }\end{array}$ & $\begin{array}{l}\text { To examine the } \\
\text { significance of } \\
\text { communal eating } \\
\text { among adults from } \\
\text { Santiago, Chile. }\end{array}$ & $\begin{array}{l}24 \text { group interviews } \\
\text { were conducted in } \\
\text { Santiago with family } \\
\text { members, coworkers, } \\
\text { and friends who shared } \\
\text { meals with one another. }\end{array}$ & $\begin{array}{l}\text { The results showed that the } \\
\text { practice of commensality } \\
\text { strengthens the cohesion } \\
\text { among the members of a } \\
\text { group. However, eating } \\
\text { together also is assigned an } \\
\text { ambiguous value }\end{array}$ & $\begin{array}{l}\text { On the one hand, } \\
\text { commensality is viewed as } \\
\text { positive in enabling } \\
\text { connections with others. On } \\
\text { the other hand, participating in } \\
\text { commensality can be viewed } \\
\text { as negative, depending on the } \\
\text { characteristics of the } \\
\text { commensal group and the } \\
\text { context, something that also } \\
\text { was revealed by this study. }\end{array}$ \\
\hline
\end{tabular}


Table 2. Cont.

\begin{tabular}{|c|c|c|}
\hline $\begin{array}{l}\text { Authors } \\
\text { (Year), } \\
\text { Country }\end{array}$ & Objectives & $\begin{array}{c}\text { Methods, Settings and } \\
\text { Participants }\end{array}$ \\
\hline $\begin{array}{c}\text { Neely (2014) } \\
{[31]} \\
\text { New } \\
\text { Zealand }\end{array}$ & $\begin{array}{l}\text { To explore the } \\
\text { promotion of school } \\
\text { connectedness through } \\
\text { the practice of shared } \\
\text { lunches within a } \\
\text { secondary school. }\end{array}$ & $\begin{array}{c}\text { Teachers and } \\
\text { 16-18-year-old students } \\
\text { in a New Zealand } \\
\text { secondary school, } \\
\text { ethnographic } \\
\text { interviews }\end{array}$ \\
\hline
\end{tabular}

\section{Results/Discussions Results in Relation to Review}

Shared lunches fostered common humanity, created an informal setting, encouraging sharing, enabling inclusive participation, demonstrating sacrifice for the communal good, and facilitating experiences of diversity.
Shared lunches, as part of an overall strategy to develop a well-connected school community, are adaptable and can fit into a multitude of situations to meet different needs. The findings of this study contributed to understanding the mechanisms by which shared lunches can affect indicators of school connectedness.

The paper discusses a potential cultural transition in men's domestic meal sociality and suggest the need for studies to analyze how cooking shares similar properties to commensality, and the implications of this regarding gender relations. et al. [32]

(2017)

Sweden
To explore how 31

Swedish men talk about the sociality of domestic cooking in everyday life
31 Swedish men 22-88 years old, interviews with interview guide

Domestic cooking studies can show how Swedish men express sociality of cooking, intertwined with accomplishments of masculinity. The sociality of cooking is a way for men to maintain heterosocial relationships and assume domestic responsibility.

The organization of work, time, and place had a major

To investigate how the

Nyberg,

Lennernäs

Wiklund

(2016) [33]

Sweden organization of work,

time, and place influence the food and meal situation, focusing on patterns, form and social context of meals.
Flight attendants (Scandinavia), qualitative

semi-structured interviews. influence on the meal situation and how meals were managed by FAs. The work was fragmented and inconsistent resulting in scattered meals and a more snack-based form of eating.

The table is a significant component of meals.

Regarding the couch, it seems that the family chose to eat there, as a more casual and relaxed setting. Eating in bed was related to precarity, intimacy, and casualness. In the three settings, watching television was a common practice.

Positive and negative memories of hospitality encounters for different family members are illustrated through the emotive concepts of commensality and spatiality.
The findings demonstrated the individual responsibility to solve the meal at work, e.g., to solve organizational times

Commensality was seen as an important practice in different settings and contexts. The table emerged as the cornerstone of commensality. When a table was not present, new arrangements were made. Especially the couch seems to be a new commensal space, able to allow some collective conviviality. Finally, the significant role that television assumed in meals was also highlighted.

Family meals take on symbolic and publicly celebrated

characteristics, whereas shared accommodation space is contested. Theoretical implications of the nature of family hospitality dimensions are further discussed. 
Table 2. Cont.

\begin{tabular}{|c|c|c|c|}
\hline $\begin{array}{c}\text { Authors } \\
\text { (Year), } \\
\text { Country }\end{array}$ & Objectives & $\begin{array}{c}\text { Methods, Settings and } \\
\text { Participants }\end{array}$ & Results/Discussions \\
\hline $\begin{array}{c}\text { Sidenvall } \\
\text { et al. (2000) } \\
{[36]} \\
\text { Sweden }\end{array}$ & $\begin{array}{c}\text { To delineate the } \\
\text { meaning of preparing, } \\
\text { cooking, and serving } \\
\text { meals among retired } \\
\text { single living cohabiting } \\
\text { women. }\end{array}$ & $\begin{array}{l}\text { Sixty-three women } \\
\text { living in two Swedish } \\
\text { cities and their rural } \\
\text { surroundings } \\
\text { participated in } \\
\text { qualitative interviews, } \\
\text { home visits. }\end{array}$ & $\begin{array}{l}\text { The whole procedure of } \\
\text { preparing a meal could be } \\
\text { seen as preparing a gift. } \\
\text { Four phases were } \\
\text { identified: finding out } \\
\text { what to serve, cooking, } \\
\text { presenting the gift in a } \\
\text { beautiful manner, and } \\
\text { enjoying the commensality }\end{array}$ \\
\hline
\end{tabular}

To explore the extent to which family meal

Skafida occurrence, meal

(2013) [37] patterns and perceived

UK

meal enjoyment predict

the quality of children's diets.
Scottish sample of five-year-old children, face-to-face structured interviews with child and mother.
Eating the same food as parents is the aspect of family meals most strongly linked to better diets in children, highlighting the detrimental effect in the rise of "children's food."

Results in Relation to Review

Cohabiting women went on cooking with duty and joy as they had done before retirement. For widows, especially those who had recently lost their spouse, the meaning of cooking and eating was lost, and among these women there was a risk of poor nutritional intake.

The results suggested that eating together was a far less important aspect of family meals and redirects attention away from issues of form and function towards issues of food choice. Policy implications and the importance for public health to recognize the way eating habits are defined and reproduce social and cultural capital are discussed.

Meal commensality varied across the daily cycle: Many spouses skipped breakfast or ate breakfast separately, most ate lunch at work, and dinner was the main commensal meal. semi-structure interviews.
To study commensal patterns of people entering marriage.
Twenty couples in the

$\begin{array}{cc}\text { Rauschen- } & \text { To study commensal } \\ \text { bach (2002) } & \text { patterns of people } \\ \text { [38] } & \text { entering marriage. } \\ \text { USA } & \end{array}$

To evaluate food habits in a holistic way, identifying key elements of the Tessler S, (2005) [39] France Mediterranean dietary model.

$\begin{array}{cc}\text { Traphagan } & \text { To study eating } \\ \text { JW, Brown } & \text { patterns and attitudes } \\ \text { LK. (2019) } & \text { within fast food } \\ \text { [40] } & \text { restaurants in Japan. } \\ \text { Japan } & \end{array}$

Mother-daughter couples in Sardinia (63) and Malta (61), qualitative questionnaire, open-ended, anthropological study.

Previously collected, listing, casual conversation interviews and observations, qualitative data from three cities in Japan. ethnographic free
The evening meal was seen to be the socializing meal in both islands. In Sardinia, both lunch and dinner were eaten together with family at home.

The authors are claiming that McDonalds and other fast food chains are

thriving in Japan due to the way such fast-food establishments resonate with other parts of Japanese life and culture.
Greater marital commensality occurred on weekends than weekdays. Kin were major participants in commensal circles, with friends, coworkers, and neighbors also included as eating partners.

Mostly open-ended questions, which means a qualitative approach, showing the importance of the evening meal for socialization, lunches involving family members.

Several different methods of collecting data, including free listing, casual conversation interviews and observations describing eating patterns and attitudes at fast food establishments in Japan
Widowhood meant significantly fewer opportunities for commensality. Participants attributed changes to their food behaviors due to the experienced difference between shared meals and meals eaten alone, no longer having the commitment of commensality.
Free from the commitment of commensality, some shifted away from regular meals and simplified their meal preparation strategies. This has implications for clinical and research endeavors. 
Table 3. Ethnology: summary of the reviewed studies $(n=6)$.

\begin{tabular}{|c|c|c|c|c|}
\hline $\begin{array}{l}\text { Authors (Year), } \\
\text { Country }\end{array}$ & Objectives & $\begin{array}{l}\text { Method, Settings } \\
\text { and Participants }\end{array}$ & Results/Discussions & Results in Relation to Review \\
\hline $\begin{array}{c}\text { Ahn Nelson } \\
\text { (2015) [42] } \\
\text { USA }\end{array}$ & $\begin{array}{l}\text { To examine the } \\
\text { behaviors and social } \\
\text { interactions among } \\
\text { preschool children and } \\
\text { their teachers during } \\
\text { food consumption at a } \\
\text { daycare facility, using } \\
\text { social cognitive theory. }\end{array}$ & $\begin{array}{c}\text { Qualitative, } \\
\text { ethnographic } \\
\text { methods for } \\
\text { studying } \\
\text { pre-school } \\
\text { children in a US } \\
\text { daycare center. }\end{array}$ & $\begin{array}{l}\text { Teachers' food socialization } \\
\text { styles and social interactions } \\
\text { with peers cultivated } \\
\text { children's food consumption. } \\
\text { Commensality rules set by } \\
\text { the childcare institution also } \\
\text { helped children learn other } \\
\text { valuable behaviors. }\end{array}$ & $\begin{array}{l}\text { The findings showed that } \\
\text { teachers' socialization styles } \\
\text { and social interactions had a } \\
\text { profound effect on children's } \\
\text { eating and meal time } \\
\text { behaviors. }\end{array}$ \\
\hline $\begin{array}{c}\text { Benbow, H. M. } \\
\text { (2018) [43] } \\
\text { Australia }\end{array}$ & $\begin{array}{l}\text { To study how sharing } \\
\text { food created } \\
\text { intercultural } \\
\text { encounters that could } \\
\text { be poignant and caring } \\
\text { or alienating and } \\
\text { divisive. }\end{array}$ & $\begin{array}{l}\text { Australian } \\
\text { soldiers and } \\
\text { locals during the } \\
\text { Battle of Timor in } \\
\text { the Second World } \\
\text { War. Memoirs } \\
\text { and stories } \\
\text { gathering }\end{array}$ & $\begin{array}{l}\text { Discourse around food } \\
\text { highlights the close } \\
\text { connections formed between } \\
\text { the commandos and their } \\
\text { local "helpers," the } \\
\text { "criados." }\end{array}$ & $\begin{array}{l}\text { These food-related experiences } \\
\text { were shown to have a } \\
\text { particular poignancy to the } \\
\text { enduring notion in the } \\
\text { Australian military of a "Debt } \\
\text { of Honour" owed to the } \\
\text { people of Timor. }\end{array}$ \\
\hline $\begin{array}{l}\text { Osowski, C. P. } \\
\text { and Y. M. } \\
\text { Sydner (2019) } \\
\text { [44] Sweden }\end{array}$ & $\begin{array}{l}\text { To study children's } \\
\text { perceptions of meals } \\
\text { with regard to what, } \\
\text { where, and with whom } \\
\text { meals are eaten and } \\
\text { how meals are made. }\end{array}$ & $\begin{array}{l}112 \text { Swedish } \\
\text { children, } \\
\text { ethnographic } \\
\text { questionnaire. }\end{array}$ & $\begin{array}{l}\text { Meals were often portrayed } \\
\text { with family members sharing } \\
\text { proper meals at home, } \\
\text { spending enjoyable time } \\
\text { together. The children } \\
\text { described festive meals, } \\
\text { which included extended } \\
\text { family and friends, other } \\
\text { foods and conditions. }\end{array}$ & $\begin{array}{l}\text { The family meal functioned as } \\
\text { a way to construct the family } \\
\text { where children acquire norms } \\
\text { and values about meals and } \\
\text { family identity, in an active } \\
\text { way, by breaking rules and by } \\
\text { challenging norms. The } \\
\text { commensal aspects } \\
\text { surrounding included both } \\
\text { commensal eating and } \\
\text { commensal food work. }\end{array}$ \\
\hline $\begin{array}{l}\text { Phull, S., et al. } \\
\text { (2015) [45] UK }\end{array}$ & $\begin{array}{c}\text { To explore the concept } \\
\text { of conviviality and its } \\
\text { significance in relation } \\
\text { to the Mediterranean } \\
\text { Diet. }\end{array}$ & $\begin{array}{l}\text { Review of lit to } \\
\text { define } \\
\text { conviviality. }\end{array}$ & $\begin{array}{l}\text { Conviviality is widely used } \\
\text { to promote the ideals of the } \\
\text { Mediterranean Diet, } \\
\text { Mediterranean culture, and } \\
\text { family life. Definitions of the } \\
\text { term conviviality suggest } \\
\text { that convivial occasions are } \\
\text { amicable, sociable occasions, } \\
\text { and pleasure is experienced } \\
\text { by all present. }\end{array}$ & $\begin{array}{l}\text { It offers an interdisciplinary } \\
\text { perspective on who and what } \\
\text { makes conviviality happen } \\
\text { and the potential obstacles to } \\
\text { the experience and promotion } \\
\text { of convivial dining. }\end{array}$ \\
\hline $\begin{array}{c}\text { Sabatini, F., et al. } \\
\text { (2016). [46] } \\
\text { Brazil }\end{array}$ & $\begin{array}{l}\text { To analyze the } \\
\text { experiences of nutrition } \\
\text { students in } \\
\text { constructing a portfolio } \\
\text { about food and culture. }\end{array}$ & $\begin{array}{l}\text { Twenty-nine } \\
\text { students, blog } \\
\text { following, family } \\
\text { gatherings, a } \\
\text { movie about food, } \\
\text { analyzing a text, } \\
\text { making a list of } \\
\text { ideas, concepts } \\
\text { and messages } \\
\text { learnt. Eleven } \\
\text { students also } \\
\text { participated in } \\
\text { focus groups }\end{array}$ & $\begin{array}{l}\text { Important messages linking } \\
\text { eating to history, culture, } \\
\text { respect and commensality. In } \\
\text { the focus groups, students } \\
\text { highlighted that the portfolio } \\
\text { helped them to reflect and to } \\
\text { change their view of } \\
\text { nutrition. The creation of the } \\
\text { portfolio was considered } \\
\text { exciting, involving and } \\
\text { demanding }\end{array}$ & $\begin{array}{l}\text { Students were stimulated } \\
\text { toward a critical, humanized, } \\
\text { and complex practice that } \\
\text { respected the historical, social, } \\
\text { cultural, sensorial, nutritional, } \\
\text { and political nature of eating. } \\
\text { The portfolio seemed a suitable } \\
\text { learning method for complex } \\
\text { themes, such as food and } \\
\text { culture, providing a } \\
\text { collaborative formation } \\
\text { process }\end{array}$ \\
\hline
\end{tabular}


Table 3. Cont.

\begin{tabular}{|c|c|c|c|c|}
\hline $\begin{array}{l}\text { Authors (Year), } \\
\text { Country }\end{array}$ & Objectives & $\begin{array}{l}\text { Method, Settings } \\
\text { and Participants }\end{array}$ & Results/Discussions & Results in Relation to Review \\
\hline $\begin{array}{l}\text { Woolley, K. and } \\
\text { A. Fishbach } \\
\text { (2017) [47] USA }\end{array}$ & $\begin{array}{l}\text { To examine the } \\
\text { consequences of } \\
\text { incidental food } \\
\text { consumption for trust } \\
\text { and cooperation. }\end{array}$ & $\begin{array}{l}\text { This study used a } \\
2 \text { (food: similar vs. } \\
\text { dissimilar) vs } 2 \\
\text { (role: investor vs. } \\
\text { fund-manager) } \\
\text { between-subjects } \\
\text { design. }\end{array}$ & $\begin{array}{l}\text { Food consumption further } \\
\text { influences conflict resolution, } \\
\text { with strangers who are } \\
\text { assigned to eat similar foods } \\
\text { cooperating more in a labor } \\
\text { negotiation, and earn more } \\
\text { money. Consumers are more } \\
\text { trusting of information about } \\
\text { non-food products. Food } \\
\text { serves as a particularly } \\
\text { strong cue of trust compared } \\
\text { with incidental similarity. }\end{array}$ & $\begin{array}{l}\text { Food serves as a particularly } \\
\text { strong cue of trust compared } \\
\text { with other incidental similarity. } \\
\text { Theoretical and practical } \\
\text { implications of this work for } \\
\text { improving interactions } \\
\text { between strangers, and for } \\
\text { marketing products were } \\
\text { discussed. }\end{array}$ \\
\hline
\end{tabular}

Table 4. Log book plus interview: summary of the reviewed studies $(n=4)$.

\begin{tabular}{|c|c|c|}
\hline $\begin{array}{c}\text { Authors } \\
\text { (Year), } \\
\text { Country }\end{array}$ & Objectives & $\begin{array}{c}\text { Methods, Settings and } \\
\text { Participants }\end{array}$ \\
\hline
\end{tabular}

$\begin{array}{ccc} & \text { To examine } & \text { Focus on family meals } \\ \text { Jarosz } & \text { social } & \text { with under-aged children. } \\ \text { (2017) [48] } & \text { differentiation } & \text { Using data from the } \\ \text { UK } & \text { in eating } & \text { 2014-2015 UK Time Use } \\ & \text { patterns in } & \text { Survey, 1 weekday and 1 } \\ & \text { Britain. } & \text { weekend day. }\end{array}$

\begin{tabular}{|c|c|c|}
\hline $\begin{array}{c}\text { Kniffin } \\
\text { (2015) [49] } \\
\text { USA }\end{array}$ & $\begin{array}{l}\text { To investigate } \\
\text { organizational } \\
\text { benefits when } \\
\text { coworkers } \\
\text { engage in } \\
\text { commensality. }\end{array}$ & $\begin{array}{l}\text { Study performed within } \\
\text { firehouses in a large city, } \\
\text { mix of qualitative and } \\
\text { quantitative including } \\
\text { group conversations and } \\
\text { interviews and } \\
\text { introductory questions. }\end{array}$ \\
\hline
\end{tabular}

\section{Results/Discussions}

The highest occupational class dedicated more time to family meals. This effect was no longer significant when controlling for education or income. Higher educated individuals had more frequent family meals, and more affluent individuals spent more time at the table with

household members.

The field research showed a significant positive association between commensality and work-group performance.
Results in Relation to Review
Household composition mattered for how people ate. Parents of younger children ate with them more frequently than parents of teenagers did. Single parents, a notoriously time-poor category, spent the least amount of time eating with their families.

To assess the association

between eating alone and the

Kwon MetS and to

(2017) [50]

Korea

identify

whether

sociodemo-

graphic factors

modify this

association.

\begin{tabular}{cc}
\hline & $\begin{array}{c}\text { This paper } \\
\text { examines } \\
\text { Paddock }\end{array}$ \\
aspects of the \\
Whillans & $\begin{array}{l}\text { experience of } \\
\text { eating out in }\end{array}$ \\
(2017) & $\begin{array}{l}2015 \text { and its } \\
\text { change over } \\
\text { t51] UK }\end{array}$ \\
& time.
\end{tabular}

This study included 7725 adults and used interviews.

\section{A repeat survey, from quota sampling,} conducted in the Spring of 2015. The third tranche of data arises from 31 follow-up, in-depth, semi-structured interviews conducted, in three cities.

The findings establish a basis for research and practice that focuses on ways that businesses or workplaces can enhance team performance by leveraging the mundane, powerful activity of eating together.

$20.8 \%$ of men and $29.2 \%$ of

women ate alone $\geq 2$

times/day. Those who ate alone 2 or more times per day showed higher frequency of living alone, having no spouse, skip meals, and less eating out. Women with eating alone $\geq 2$ times/day had a crude OR of 1.29 for MetS compared with women not eating alone.

Focus on the changing reasons and meanings of the activity as breadth of experience in the population augments and eating main meals outside the home becomes less exceptional
Eating alone $\geq 2$ times/day was significantly associated with increased abdominal obesity. This could be shown due to a combination of commensality and weight characteristics, interviews.
Ordinary events have become more prevalent, and the paper delineates two forms of "ordinary" occasions: the "impromptu" and the

"regularized." It describes the consequences for understanding the social significance of eating out, its informalization and normalization. 
Table 5. Case studies: Summary of the reviewed studies $(n=2)$.

\begin{tabular}{|c|c|c|c|c|}
\hline $\begin{array}{l}\text { Authors (Year), } \\
\text { Country }\end{array}$ & Objectives & $\begin{array}{l}\text { Method, Settings and } \\
\text { Participants }\end{array}$ & Results/Discussions & $\begin{array}{c}\text { Results in Relation to } \\
\text { Review }\end{array}$ \\
\hline $\begin{array}{c}\text { Bardone (2017) } \\
\text { [52] Estonia }\end{array}$ & $\begin{array}{l}\text { To examine how } \\
\text { pop-up restaurants } \\
\text { challenge borders } \\
\text { between private and } \\
\text { public, business and } \\
\text { entertainment. }\end{array}$ & $\begin{array}{l}\text { Autoethnography and } \\
\text { applied cultural } \\
\text { analysis. Interviews, } \\
\text { observations, website, } \\
\text { Facebook, and weblog } \\
\text { analysis including text } \\
\text { and photos in the } \\
\text { printed press }\end{array}$ & $\begin{array}{l}\text { Culture theory as a set of } \\
\text { complementary theories is } \\
\text { seen to include and } \\
\text { combine the approaches of } \\
\text { different branches of } \\
\text { science. }\end{array}$ & $\begin{array}{l}\text { By extending the borders } \\
\text { of the conventional } \\
\text { restaurant or the home into } \\
\text { public space, the pop-up } \\
\text { restaurants create spaces of } \\
\text { negotiation between the } \\
\text { private and the public and } \\
\text { new forms of } \\
\text { commensality seemed to } \\
\text { appear according to culture } \\
\text { theory. }\end{array}$ \\
\hline $\begin{array}{l}\text { Marovelli (2018) } \\
\text { [53] Ireland }\end{array}$ & $\begin{array}{l}\text { This paper focuses on a } \\
\text { type of commensality } \\
\text { created by bringing } \\
\text { together diverse } \\
\text { participants beyond } \\
\text { kinship relations and } \\
\text { celebratory feasting. }\end{array}$ & $\begin{array}{l}\text { Case study. Urban food } \\
\text { sharing initiatives in } \\
\text { London-a city which } \\
\text { exhibits an active and } \\
\text { dynamic urban food } \\
\text { sharing ecosystem. }\end{array}$ & $\begin{array}{l}\text { Social isolation and } \\
\text { loneliness emerge as } \\
\text { central drivers for } \\
\text { participating in food } \\
\text { sharing initiatives. } \\
\text { Collective spaces and the } \\
\text { affective qualities that they } \\
\text { generate are particularly } \\
\text { vital in urban contexts in } \\
\text { times of austerity, as these } \\
\text { initiatives have capacity to } \\
\text { embrace social differences } \\
\text { and to facilitate circulation } \\
\text { of ideas and practices. }\end{array}$ & $\begin{array}{l}\text { Identifies provisional } \\
\text { bridging mechanisms } \\
\text { between people, } \\
\text { communities, projects, and } \\
\text { services, exploring the } \\
\text { connective ways which are } \\
\text { hard to measure through } \\
\text { quantitative measures and, } \\
\text { are rarely articulated. }\end{array}$ \\
\hline
\end{tabular}

Table 6. Diverse methods: summary of the reviewed studies $(\mathrm{n}=21)$.

\begin{tabular}{|c|c|c|c|c|}
\hline $\begin{array}{l}\text { Authors } \\
\text { (Year), } \\
\text { Country }\end{array}$ & Objectives & $\begin{array}{l}\text { Methods, Settings and } \\
\text { Participants }\end{array}$ & Results/Discussions & $\begin{array}{c}\text { Results in Relation to } \\
\text { Review }\end{array}$ \\
\hline $\begin{array}{c}\text { Ares (2013) } \\
\text { [54] } \\
\text { Uruguay }\end{array}$ & $\begin{array}{l}\text { The aim of the present } \\
\text { work was to investigate } \\
\text { consumers' perception } \\
\text { of wellbeing in a } \\
\text { food-related context } \\
\text { using an exploratory } \\
\text { qualitative approach. }\end{array}$ & $\begin{array}{l}120 \text { Uruguayan } \\
\text { participants using three } \\
\text { qualitative techniques: } \\
\text { Word association, } \\
\text { open-ended questions, } \\
\text { and free listing. }\end{array}$ & $\begin{array}{l}\text { The expected effects of foods } \\
\text { on wellbeing were mainly } \\
\text { related to non-communicable } \\
\text { diseases such as high } \\
\text { cholesterol levels, } \\
\text { hypertension, and } \\
\text { cardiovascular diseases. }\end{array}$ & $\begin{array}{l}\text { Hedonic and emotional } \\
\text { aspects of food } \\
\text { consumption were } \\
\text { important for consumers' } \\
\text { perceived wellbeing. } \\
\text { Development of scales for } \\
\text { measuring consumer } \\
\text { perceived wellbeing when } \\
\text { eating alone or in company. }\end{array}$ \\
\hline $\begin{array}{c}\text { Boulos (2016) } \\
\text { [55] } \\
\text { Lebanon }\end{array}$ & $\begin{array}{l}\text { The purpose of the } \\
\text { present study was to } \\
\text { evaluate the association } \\
\text { between three } \\
\text { components of social } \\
\text { isolation: social } \\
\text { network, feeling of } \\
\text { loneliness, } \\
\text { commensality and } \\
\text { nutritional status. }\end{array}$ & $\begin{array}{l}\text { A total of } 1200 \\
\text { randomly selected } \\
\text { elderly individuals } \\
\text { aged } \geq 65 \text { years and } \\
\text { living in rural areas of } \\
\text { Lebanon participated } \\
\text { in the present study. } \\
\text { Face to face interviews. }\end{array}$ & $\begin{array}{l}\text { Both social isolation and } \\
\text { loneliness were } \\
\text { independently associated } \\
\text { with a higher risk of } \\
\text { malnutrition. However, no } \\
\text { association was found } \\
\text { between the frequency of } \\
\text { sharing meals and the risk of } \\
\text { malnutrition. }\end{array}$ & $\begin{array}{l}\text { The present study showed } \\
\text { that social isolation and } \\
\text { subjective loneliness are } \\
\text { two independent risk } \\
\text { factors for malnutrition } \\
\text { among older people. }\end{array}$ \\
\hline
\end{tabular}


Table 6. Cont.

\begin{tabular}{|c|c|c|c|c|}
\hline $\begin{array}{c}\text { Authors } \\
\text { (Year), } \\
\text { Country }\end{array}$ & Objectives & $\begin{array}{l}\text { Methods, Settings and } \\
\text { Participants }\end{array}$ & Results/Discussions & $\begin{array}{c}\text { Results in Relation to } \\
\text { Review }\end{array}$ \\
\hline $\begin{array}{l}\text { Ferdous (2016) } \\
\text { [56] Australia }\end{array}$ & $\begin{array}{l}\text { Exploring this tension } \\
\text { and present a novel } \\
\text { system TableTalk, } \\
\text { which transforms } \\
\text { personal devices into a } \\
\text { communal shared } \\
\text { display on the table to } \\
\text { enrich mealtime } \\
\text { interactions and } \\
\text { experience. }\end{array}$ & $\begin{array}{c}\text { Tabletalk design } \\
\text { including nine families. }\end{array}$ & $\begin{array}{l}\text { Our field study shows that } \\
\text { TableTalk does not } \\
\text { undermine togetherness, but } \\
\text { supports familial } \\
\text { expectations and experiences } \\
\text { by stimulating conversation, } \\
\text { reminiscing, bonding, } \\
\text { education, and socializing. }\end{array}$ & $\begin{array}{l}\text { The paper discusses how } \\
\text { technology that is sensitive } \\
\text { to the needs of family } \\
\text { interactions can augment } \\
\text { the commensal experience } \\
\text { and reflect on design } \\
\text { choices and opportunities } \\
\text { that contribute, rather than } \\
\text { disrupt, family mealtimes }\end{array}$ \\
\hline $\begin{array}{c}\text { Ferdous [57] } \\
\text { (2017) } \\
\text { Australia }\end{array}$ & $\begin{array}{l}\text { This paper presents the } \\
\text { deployment of a } \\
\text { mealtime technology } \\
\text { that orchestrates the } \\
\text { sharing of personal } \\
\text { devices and stories } \\
\text { during family } \\
\text { mealtimes, explores } \\
\text { related content from all } \\
\text { participants' devices. }\end{array}$ & $\begin{array}{l}\text { Seven families. Field } \\
\text { study to use CHORUS. } \\
\text { We began the initial } \\
\text { visits at participants' } \\
\text { home with an interview } \\
\text { with all members of the } \\
\text { family including } \\
\text { children. }\end{array}$ & $\begin{array}{l}\text { Family interactions through } \\
\text { sharing contents of personal } \\
\text { and familial significance, } \\
\text { supports togetherness and } \\
\text { in-depth discussion by } \\
\text { combining resources from } \\
\text { multiple devices, helps to } \\
\text { broach sensitive topics into } \\
\text { familial conversation, and } \\
\text { encourages participation } \\
\text { from all family members. }\end{array}$ & $\begin{array}{l}\text { This paper discusses the } \\
\text { implications of this } \\
\text { research and reflects on } \\
\text { design choices and } \\
\text { opportunities that can } \\
\text { further enhance the family } \\
\text { mealtime experience using } \\
\text { the CHORUS mealtime } \\
\text { technology. }\end{array}$ \\
\hline $\begin{array}{c}\text { Giacoman } \\
\text { (2017) [58] } \\
\text { Chile }\end{array}$ & $\begin{array}{l}\text { The purpose of this } \\
\text { paper is to explore the } \\
\text { daily rhythms of eating, } \\
\text { namely, the times at } \\
\text { which food intake } \\
\text { occurs during a } \\
\text { day-long period. }\end{array}$ & $\begin{array}{l}\text { The data used in this } \\
\text { research come from a } \\
\text { first time-use survey } \\
\text { applied in Santiago in } \\
2007 \text { and 2008, which } \\
\text { works with a } \\
\text { retrospective activity } \\
\text { journal to document } \\
\text { the amount of time } \\
\text { dedicated to different } \\
\text { activities in } 2282 \text { cases } \\
\text { during the } 24 \text { h of the } \\
\text { previous day. }\end{array}$ & $\begin{array}{l}\text { This study shows that people } \\
\text { in Santiago tend to eat } \\
\text { according to the same } \\
\text { timetable (morning, midday } \\
\text { and evening) and that } \\
\text { socio-demographic variables } \\
\text { have limited influence on the } \\
\text { synchronization of this } \\
\text { intake between Monday and } \\
\text { Friday. }\end{array}$ & $\begin{array}{l}\text { These results yield } \\
\text { evidence that calls into } \\
\text { question the applicability } \\
\text { of the thesis of } \\
\text { alimentary modernity } \\
\text { within a Latin American } \\
\text { context, which has not } \\
\text { before been subject to } \\
\text { investigation-time use } \\
\text { study. }\end{array}$ \\
\hline $\begin{array}{c}\text { Gorman- } \\
\text { Murray (2016) } \\
\text { [59] } \\
\text { Australia } \\
\text { Canada }\end{array}$ & $\begin{array}{l}\text { To examine the recent } \\
\text { transformations in } \\
\text { consumer landscapes } \\
\text { and leisure spaces in } \\
\text { inner city LGBT } \\
\text { neighborhoods. }\end{array}$ & $\begin{array}{l}\text { The study included } \\
\text { consumer landscapes } \\
\text { and leisure spaces in } \\
\text { inner city LGBT } \\
\text { neighborhoods in } \\
\text { Sydney, Australia and } \\
\text { Toronto, Canada, } \\
\text { investigated through } \\
\text { case studies. }\end{array}$ & $\begin{array}{l}\text { Practices and spaces of } \\
\text { leisure-based consumption } \\
\text { are emerging in different } \\
\text { forms across these } \\
\text { neighborhoods. Deploying a } \\
\text { discourse analysis of } \\
\text { mainstream newspaper } \\
\text { articles supplemented by } \\
\text { relevant LGBT press releases, } \\
\text { focusing on the use, meaning } \\
\text { and social significance of } \\
\text { leisure-based consumption } \\
\text { sites-clubs, bars, cafes, } \\
\text { restaurants. }\end{array}$ & $\begin{array}{l}\text { The balance of } \\
\text { daytime/night-time leisure } \\
\text { spaces, which have both } \\
\text { social and material } \\
\text { affordances, is a key } \\
\text { discriminator across the } \\
\text { neighborhoods. Daytime } \\
\text { consumer landscapes are } \\
\text { often framed as sociable } \\
\text { and inclusive within the } \\
\text { media, while night-time } \\
\text { landscapes are perceived } \\
\text { as divisive. }\end{array}$ \\
\hline
\end{tabular}


Table 6. Cont.

\begin{tabular}{|c|c|c|c|c|}
\hline $\begin{array}{l}\text { Authors } \\
\text { (Year), } \\
\text { Country }\end{array}$ & Objectives & $\begin{array}{l}\text { Methods, Settings and } \\
\text { Participants }\end{array}$ & Results/Discussions & $\begin{array}{c}\text { Results in Relation to } \\
\text { Review }\end{array}$ \\
\hline $\begin{array}{l}\text { Gorringe } \\
\text { (2015) [60] } \\
\text { USA }\end{array}$ & $\begin{array}{l}\text { To present a qualitative } \\
\text { descriptive case study } \\
\text { of leadership and } \\
\text { organization } \\
\text { development } \\
\text { philosophy and to } \\
\text { summarize a strategy } \\
\text { for using intentional } \\
\text { organization design as } \\
\text { a foundation for } \\
\text { culturally aligned } \\
\text { physician leadership } \\
\text { development. }\end{array}$ & $\begin{array}{c}\text { Mayo Clinic leadership } \\
\text { development. } \\
\text { Qualitative descriptive } \\
\text { case study. }\end{array}$ & $\begin{array}{l}\text { The authors identified four } \\
\text { intentional characteristics of } \\
\text { the multi-specialty group } \\
\text { practice structure and culture } \\
\text { that organically facilitate the } \\
\text { development of leaders with } \\
\text { the qualities required for the } \\
\text { mission. }\end{array}$ & $\begin{array}{l}\text { Development cannot be } \\
\text { separated from the context } \\
\text { and culture of } \\
\text { organizational design. } \\
\text { Organizational systems are } \\
\text { designed to develop } \\
\text { culturally aligned leaders, } \\
\text { build social capital, grow } \\
\text { employee engagement, } \\
\text { foster collaboration, } \\
\text { nurture collegiality, and } \\
\text { engender trust. } \\
\text { Organization design aligns } \\
\text { the form and functions } \\
\text { with leadership } \\
\text { development and its } \\
\text { mission. }\end{array}$ \\
\hline $\begin{array}{l}\text { Henig (2016) } \\
\text { [61] } \\
\text { UK }\end{array}$ & $\begin{array}{l}\text { To explore how the } \\
\text { notion of sofra } \\
\text { [table/dining etiquette] } \\
\text { is deployed by a } \\
\text { Muslim Dervish } \\
\text { brotherhood in a post- } \\
\text { cosmopolitan town in } \\
\text { post-war } \\
\text { Bosnia-Herzegovina. }\end{array}$ & $\begin{array}{l}\text { The aim was to show } \\
\text { that mediations, } \\
\text { orchestrated as } \\
\text { hospitality events, can } \\
\text { be conceived of as a } \\
\text { form of } \\
\text { sofra-diplomacy, in } \\
\text { developing an } \\
\text { ethnography of } \\
\text { everyday diplomacy. }\end{array}$ & $\begin{array}{l}\text { Suggests that the notion of } \\
\text { sofra embodies both a mode } \\
\text { of being diplomatic as well } \\
\text { as a site of everyday } \\
\text { diplomacy }\end{array}$ & $\begin{array}{l}\text { The sofra enables the } \\
\text { brotherhood to stage } \\
\text { "events of hospitality" and } \\
\text { mediate relationships } \\
\text { between various "others," } \\
\text { locally and transnationally. } \\
\text { There are two primary } \\
\text { "sites" of } \\
\text { post-cosmopolitan } \\
\text { everyday diplomacy where } \\
\text { shared urban civility, } \\
\text { instantiated primarily } \\
\text { through acts of } \\
\text { commensality, namely the } \\
\text { lodge and the soup kitchen. }\end{array}$ \\
\hline $\begin{array}{l}\text { Hopkins } \\
\text { (2018) [62] } \\
\text { Egypt }\end{array}$ & $\begin{array}{l}\text { This paper describes } \\
\text { the set of beliefs that } \\
\text { underlie visit behavior } \\
\text { and the sequence of } \\
\text { events in visits to } \\
\text { several of these shrines. } \\
\text { Analysis was based on } \\
\text { the human social } \\
\text { relations. }\end{array}$ & $\begin{array}{l}\text { The land in the Testour } \\
\text { area in the early 1970s, } \\
\text { historical anthropology. } \\
\text { It is thus a form of } \\
\text { historical anthropology. } \\
\text { The approach is } \\
\text { ethnographic, with a } \\
\text { focus on people and } \\
\text { events rather than on } \\
\text { texts. }\end{array}$ & $\begin{array}{l}\text { The visits involve prayer, } \\
\text { commensality, and recreation. } \\
\text { The shrines and the visits } \\
\text { range from the simple to the } \\
\text { complex. The occasional } \\
\text { successful visit validates the } \\
\text { system of beliefs and } \\
\text { prepares for the next visit. }\end{array}$ & $\begin{array}{l}\text { The collective aspect of the } \\
\text { visits reinforces social } \\
\text { relations within the groups } \\
\text { of families and neighbors. } \\
\text { These rituals can be } \\
\text { transferred in the form of } \\
\text { shared food and drink, and } \\
\text { justifies a lot of } \\
\text { commensality. }\end{array}$ \\
\hline
\end{tabular}


Table 6. Cont.

\begin{tabular}{|c|c|c|c|c|}
\hline $\begin{array}{l}\text { Authors } \\
\text { (Year), } \\
\text { Country }\end{array}$ & Objectives & $\begin{array}{l}\text { Methods, Settings and } \\
\text { Participants }\end{array}$ & Results/Discussions & $\begin{array}{c}\text { Results in Relation to } \\
\text { Review }\end{array}$ \\
\hline $\begin{array}{c}\text { Lawson (2018) } \\
\text { [63] } \\
\text { UK }\end{array}$ & $\begin{array}{l}\text { To study how exchange } \\
\text { invited modes of } \\
\text { collective, } \\
\text { interconnected, and } \\
\text { multifarious } \\
\text { participation, which } \\
\text { unsettled the cultural } \\
\text { function of cakes as } \\
\text { gendered, } \\
\text { asymmetrical gifts, and } \\
\text { the potential of cakes to } \\
\text { develop generosity. }\end{array}$ & $\begin{array}{l}\text { Fieldwork baking and } \\
\text { investigating cakes in } \\
\text { performance since } 2009 \\
\text { through a series of } \\
\text { works that invited the } \\
\text { audience to share a } \\
\text { memory of a significant } \\
\text { person, place, time, or } \\
\text { cake; in return, I baked } \\
\text { their memories into } \\
\text { unique cakes dedicated } \\
\text { to those memories. }\end{array}$ & $\begin{array}{l}\text { Through the signifying } \\
\text { potential of cakes and the } \\
\text { process of baking together, } \\
\text { the performances evoked a } \\
\text { multiplicity of complex } \\
\text { emotional experiences. The } \\
\text { baking performances echoed } \\
\text { established symbolic uses of } \\
\text { cake in commemorative } \\
\text { practices including festive } \\
\text { meals, celebrations, and } \\
\text { religious ceremonies. }\end{array}$ & $\begin{array}{l}\text { Cakes' ability to move a } \\
\text { community through the } \\
\text { integration of } \\
\text { commemoration, } \\
\text { evidenced most acutely in } \\
\text { the willingness of } \\
\text { participants to embrace in } \\
\text { the creative, symbolic } \\
\text { potential of cake. Cakes are } \\
\text { powerful objects in } \\
\text { performance that can } \\
\text { intervene in a community } \\
\text { of strangers and map new } \\
\text { avenues of commensality. }\end{array}$ \\
\hline $\begin{array}{c}\text { Madden } \\
\text { (2015) [64] US }\end{array}$ & $\begin{array}{l}\text { This essay to a special } \\
\text { issue on utopian } \\
\quad \text { foodways } \\
\text { acknowledges specific } \\
\text { details of some of these } \\
\text { changes and } \\
\text { intersections, explains } \\
\text { the origin of the issue. }\end{array}$ & $\begin{array}{l}\text { Workshop at the } \\
\text { University of Kansas, } \\
\text { overview of included } \\
\text { essays. }\end{array}$ & $\begin{array}{l}\text { Thematically, they include } \\
\text { analyses of images of } \\
\text { abundance and lack in the } \\
\text { past, "real" practices in the } \\
\text { past and present, and } \\
\text { imagined eating in the } \\
\text { future. }\end{array}$ & $\begin{array}{l}\text { The essay concludes with a } \\
\text { call for "speculative" } \\
\text { futures in research, writing, } \\
\text { and teaching about utopian } \\
\text { food practices including } \\
\text { commensality. }\end{array}$ \\
\hline $\begin{array}{l}\text { Masson (2017) } \\
\text { France [65] }\end{array}$ & $\begin{array}{l}\text { To place dietary } \\
\text { practices into a general } \\
\text { context in which the } \\
\text { relationship to food } \\
\text { tends to be } \\
\text { individualized and in } \\
\text { which health-related } \\
\text { issues remain an } \\
\text { important aspect of the } \\
\text { discourse about food } \\
\text { on Internet. }\end{array}$ & $\begin{array}{c}\text { Content analysis on } \\
\text { fifty French individuals } \\
\text { ( } 25 \text { females, } 25 \text { males) } \\
\text { aged between } 18 \text { and } 60 \\
\text { years old and with } \\
\text { varied socio-economic } \\
\text { profiles. }\end{array}$ & $\begin{array}{l}\text { Food sharing is strongly } \\
\text { promoted and solitary } \\
\text { refection heavily frowned } \\
\text { upon, the sole purpose of } \\
\text { eating not being to nourish } \\
\text { the physical body, but also to } \\
\text { nourish the social body and } \\
\text { connections with others. }\end{array}$ & $\begin{array}{l}\text { The method, can be used } \\
\text { for studying commensality. } \\
\text { Although a personalized } \\
\text { diet restricts the objective } \\
\text { possibilities of food } \\
\text { sharing, it is still central in } \\
\text { representations of food, } \\
\text { leads to the emergence of } \\
\text { associated practices to } \\
\text { introduce new forms of } \\
\text { social eating behaviors, as } \\
\text { those spread of the } \\
\text { Internet. }\end{array}$ \\
\hline $\begin{array}{l}\text { O'Connor } \\
\text { et al. (eds) } \\
2015 \text { [66] } \\
\text { UK }\end{array}$ & $\begin{array}{l}\text { To "analyze } \\
\text { commensality in all its } \\
\text { forms" and to make the } \\
\text { point that "not all } \\
\text { people in the world eat } \\
\text { around a table or a } \\
\text { common hearth-in } \\
\text { fact, there are } \\
\text { insurmountable } \\
\text { variations of all kinds." }\end{array}$ & $\begin{array}{l}\text { This theoretically } \\
\text { orientated edited } \\
\text { volume proposes to } \\
\text { examine sociality } \\
\text { through six "mid-level } \\
\text { concepts": disjuncture, } \\
\text { social field, social space, } \\
\text { sociability, } \\
\text { organization, and } \\
\text { network. }\end{array}$ & $\begin{array}{l}\text { "Commensality"—which at } \\
\text { its most basic means "eating } \\
\text { together"—suggests social } \\
\text { relationships without } \\
\text { defining or describing them } \\
\text { in detail. }\end{array}$ & $\begin{array}{l}\text { Unsurprisingly, there are } \\
\text { many contesting } \\
\text { definitions of } \\
\text { commensality-the } \\
\text { introduction lists them all, } \\
\text { a long menu-leaving } \\
\text { contributors free to choose } \\
\text { their own interpretation, } \\
\text { inevitably mixing levels of } \\
\text { analysis. While food is a } \\
\text { natural organizing theme, } \\
\text { it does not play that role } \\
\text { here. }\end{array}$ \\
\hline
\end{tabular}


Table 6. Cont.

\begin{tabular}{|c|c|c|}
\hline $\begin{array}{l}\text { Authors } \\
\text { (Year), } \\
\text { Country }\end{array}$ & Objectives & $\begin{array}{c}\text { Methods, Settings and } \\
\text { Participants }\end{array}$ \\
\hline $\begin{array}{l}\text { Pachucki, et al. } \\
2018 \text { [67] USA }\end{array}$ & $\begin{array}{l}\text { This study evaluates } \\
\text { how social aspects of } \\
\text { eating-frequencies of } \\
\text { eating meals with } \\
\text { others, meals prepared } \\
\text { at home, and meals } \\
\text { outside the home-are } \\
\text { associated with } \\
\text { nutrient intake. }\end{array}$ & $\begin{array}{l}\text { Sex-stratified multiple } \\
\text { regression analyses } \\
\text { adjusted for } \\
\text { confounders assessed } \\
\text { the relationship } \\
\text { between frequency of } \\
\text { eating with others and } \\
\text { nutrient intake } \\
\text { multi-ethnic cohort } \\
\text { type } 2 \text { diabetics re } \\
\text { social aspects of diet }\end{array}$ \\
\hline
\end{tabular}

Results/Discussions in Relation to
Review

There was no consistently significant association between meals with others and the 5 nutrient intake measures for either men or women. The directions of association between categories of eating with others and diet quality-albeit not significant were different for men (positive) and women (mostly negative), which warrants further investigation.

Greater meal frequency at home was associated with significantly better scores on diet quality indices for men, while meal frequency outside the home was associated with poorer diet quality and energy intake for women. Better measurement of eating may inform ways to improve nutrition, especially for persons with diabetes for whom diet improvement can result in better disease outcomes.

Western notions of public space can be seen as designed green places of relief from industrial and commercial concentration. Personal experience and a range of secondary literature an alternative way of thinking about the streets and the national cultural space is proposed, less officious, less bureaucratic, less national, than has been allowed so far in considerations of good taste.

There was no substantial

Telephone interviews of 6000 representative adults from France,

Germany, Italy, Switzerland, the UK, and the USA, included two items on attitudes to variety.

To study attitudes

Rozin et al. toward large numbers of choices in the food domain.

$$
\text { to variety. }
$$

\section{Brief one-page (two-sided)}

questionnaires were distributed to

individuals waiting alone in major train stations in Philadelphia and Paris.

Questionnaire based on results from focus groups relation between a variety of demographic variables and variety preferences or expectations, except that older people were less inclined to prefer the high (50) variety in ice cream choices.
Western notions of public space as designed green places of relief from urbanity are inadequate theoretical frames that cannot account for the sidewalk, the paan-shop, or the tea-stall, as sites of commensality, conviviality, and potential violence.

The results suggest that the US, and the UK to some extent, focus on providing choices that cater to individual differences in preferences, whereas the continental European countries are more attached to communal eating values.
Rozin et al. 2011 [70] USA
Three different questionnaires were distributed

\section{Compared to the French,}

Americans emphasize quantity rather than quality in making choices, have a higher preference for variety, and usually prefer comforts over joys. American preference for quantity over quality is discussed in terms of the American focus on abundance as opposed to the French preference for moderation.
The American preference for variety is reflective of Americans' more personal as opposed to communal food and other values. 
Table 6. Cont.

\begin{tabular}{|c|c|c|c|c|}
\hline $\begin{array}{l}\text { Authors } \\
\text { (Year), } \\
\text { Country }\end{array}$ & Objectives & $\begin{array}{l}\text { Methods, Settings and } \\
\text { Participants }\end{array}$ & Results/Discussions & $\begin{array}{c}\text { Results in Relation to } \\
\text { Review }\end{array}$ \\
\hline $\begin{array}{l}\text { Soulaimani } \\
\text { (2017) [71] } \\
\text { Morocco }\end{array}$ & $\begin{array}{l}\text { Examines an oral story } \\
\text { that displays how } \\
\text { embodiment is crucial } \\
\text { for understanding } \\
\text { language in interaction. }\end{array}$ & $\begin{array}{l}\text { A shopkeeper recounts } \\
\text { an unusual dining } \\
\text { event, started with } \\
\text { commensality and } \\
\text { ended with a physical } \\
\text { dispute. Enacting its } \\
\text { events, and displays } \\
\text { stance through intricate } \\
\text { forms of embodiment, } \\
\text { and different ways of } \\
\text { producing and copying } \\
\text { gestures. }\end{array}$ & $\begin{array}{l}\text { Analysis shows that telling a } \\
\text { story, beyond a matter of } \\
\text { verbal narrative, is } \\
\text { performed through } \\
\text { embodied enactments to } \\
\text { allow for achieving } \\
\text { co-participation and } \\
\text { alignment }\end{array}$ & $\begin{array}{l}\text { The data reveal a unique } \\
\text { way of intensifying } \\
\text { storytelling through both } \\
\text { verbal and embodied } \\
\text { repetition of selected story } \\
\text { events. }\end{array}$ \\
\hline $\begin{array}{l}\text { Warde, Yates } \\
\text { (2017) [72] UK }\end{array}$ & $\begin{array}{l}\text { Understanding Eating } \\
\text { Events: Snacks and } \\
\text { Meal Patterns in Great } \\
\text { Britain. }\end{array}$ & $\begin{array}{l}\text { Conducted in Great } \\
\text { Britain in } 2012(\mathrm{n}= \\
\text { 2784), analyzed eating } \\
\text { occasions which } \\
\text { respondents stated } \\
\text { were snacks rather than } \\
\text { meals, focusing on their } \\
\text { frequency, scheduling, } \\
\text { contents, duration and } \\
\text { social context. }\end{array}$ & $\begin{array}{l}\text { Snacks take place in } \\
\text { accordance with a common } \\
\text { and predictable schedule. } \\
\text { Snacks are smaller and less } \\
\text { structured than most meals } \\
\text { but mostly do not comprise } \\
\text { what is generically described } \\
\text { as "snack foods." Snacks are } \\
\text { shorter in duration, and less } \\
\text { sociable than other eating } \\
\text { events. }\end{array}$ & $\begin{array}{l}\text { Most meals eaten in } \\
\text { company, were planned for, } \\
\text { and wholesome. Common } \\
\text { negative evaluations } \\
\text { between and outside meals } \\
\text { have failed to appreciate } \\
\text { the range of adjunct eating } \\
\text { events and the degree to } \\
\text { which they form part of } \\
\text { aggregate patterns and } \\
\text { individual routines. } \\
\text { Interesting for snack events } \\
\text { from commensality } \\
\text { perspective. }\end{array}$ \\
\hline $\begin{array}{l}\text { Yount-André } \\
\text { (2018) [73] } \\
\text { France }\end{array}$ & $\begin{array}{l}\text { This article examines } \\
\text { how Senegalese } \\
\text { immigrants, and their } \\
\text { French-born children } \\
\text { draw on eating } \\
\text { practices to index } \\
\text { religion as an axis of } \\
\text { social differentiation, } \\
\text { producing hierarchies } \\
\text { of belonging in France. }\end{array}$ & $\begin{array}{l}120 \text { ethnographic } \\
\text { interviews with } \\
\text { members of } \\
\text { transnational } \\
\text { Senegalese families, } \\
\text { their kin, friends, and } \\
\text { acquaintances in France } \\
\text { and Senegal. Including } \\
\text { observations, audio- } \\
\text { and video-recorded } \\
\text { meals and other acts of } \\
\text { food sharing. }\end{array}$ & $\begin{array}{l}\text { Even naturalized citizens feel } \\
\text { pressure to permanently } \\
\text { perform their integration } \\
\text { according to the ever-shifting } \\
\text { demands of French } \\
\text { secularism, as "eating } \\
\text { French" is increasingly } \\
\text { defined in opposition to the } \\
\text { practices of Muslim } \\
\text { immigrants from France's } \\
\text { former colonies }\end{array}$ & $\begin{array}{l}\text { French Republicanism } \\
\text { contributes to a tiered form } \\
\text { of citizenship through } \\
\text { examination of the ways } \\
\text { that educated migrants } \\
\text { adopt the language of } \\
\text { secularism to valorize their } \\
\text { own eating practices } \\
\text { relative to other } \\
\text { transnational migrants. }\end{array}$ \\
\hline
\end{tabular}

Among these qualitative papers, two approaches were identified. The first one studying commensality to understand a phenomenon within meals, and the second to examine how to understand commensality from a meal point of view. Several papers revealed aspects of different social meanings attached to food and commensality, as well as how meaning seems to have changed over time [27,36,51]. There was also some variations around the concept, such as; commensal space, meal, eating practice, conviviality, convivial dining $[18,45,68]$.

Moreover, the diversity of the applicability of the method differed within qualitative methods, ranging from more or less rather standardized questionnaires $[14,26]$, with specific open questions, to collections of life stories [27,34]. We could also see the same variation in how data have been analyzed ranging from statistical analysis such as regression analysis [50] content analysis [65] or using grounded theory [35,41].

According to different application of theories, theories surrounding "practices" were observed as the most commonly used in interview studies [24,27,30,34], within ethno- 
graphic methodology [31] as well as in questionnaires [26]. As commensality was seen as an important practice that appears in different settings and contexts, we thereby identified a perception of the importance of commensality research for more theoretical approaches on meal and food studies.

One of the most common themes on the qualitative papers was in regards to family eating $[35,37,44,48,56,57,62]$. None of these papers investigated how to implement commensality in research, but still discussed how to understand commensality in the use of technology during meals, family rites, parents/mothers and, family activities and class. All papers emphasized the importance of the use of commensality in research as a notion for bringing new light to the understanding of meals. Another interesting finding in the analysis of the papers was in regards to pleasure and health aspects of eating together. Here in the qualitative part of our results, the identified commensality papers seemed to concentrate on enjoyment or pleasure of eating together. This was most obvious in Phull et al. [45], discussing that overall economic, time and social pressures may inhibit pleasurable family dining.

\subsection{Disciplines Identified in This Scoping Review and Number of Papers over Time}

The final papers showing up in our review turned out to be mostly from the nutrition area (28 papers); 20 of them were published in Appetite. Clinical or medical journals including pediatrics published another large part (6 papers), social science (20 papers), ethnology, anthropology (6 papers), tourism studies (1 paper), urban studies (1 paper). It seems as if the search term commensality was used in several disciplines. We did not put a limit on how old the paper in WoS could be, yet the first paper using the term commensality and fitting the inclusion criteria was identified in the year 2000. From 2000-2014, the number of papers was fairly low, only ten papers were found during this fourteen year time span. In 2015, 7 papers were found, 201614 papers, 201717 papers, 201810 papers and 2019 up to April 4 papers all including some type of description of assessment of commensality. Countries involved in commensality studies according to our search were mostly European, with some originating from New Zealand, Japan, Korea, African countries, USA, Canada and South America. Sometimes authors studied other cultures than their own.

\section{Discussion}

The diversity of disciplines identified in this review is broad and the methods used to describe or to assess commensality show the true multidisciplinarity of the subject. An important result is also that the term commensality as search term seems to be widely spread over disciplines over the last five years, while earlier research is scarce. A large proportion of the commensality research identified in this review was European, possibly indicating that the term commensality has been more used in the European arena.

A great deal of the identified research is focused on health and nutrition, aiming to investigate the importance of commensality for health and wellbeing [12-16,18,20,22,24,26, $30,33,39,46,58,65,67,69]$. This means that data on health and health related behaviors, living conditions and sociodemographic data, need to accompany the data on commensality. To gather valid data on dietary intake, solid dietary survey methodology should be used. 24-h recall in questionnaire format, with at least 224 -h recalls per individual is suggested as a good way to assess dietary quality $[4,12,15,16,19]$. Since $24-h$ recall is a type of diary, it can easily be connected to questions on with whom, where, type of venue, time of day, and type of meal consumed (breakfast, lunch, dinner, other). Furthermore, several nutritionally oriented authors expressed the need for including qualitative measures to complement the traditional quantitative data gathering $[15,16,19]$, such as open-ended questions or combining questionnaires/diaries with interviews or observations for example.

There are a couple of questionnaires that could be used for authors only interested in commensality as such $[18,19]$, while one is under development [14]. These questionnaires seem very comprehensive and describe wellbeing related to food, with commensality as 
a small part. Several authors underline the importance of employing proper sampling methods and techniques to reduce non-response or at least to try to identify a sample that finally provides you with a representative proportion of the population under investigation.

It is very surprising that so few of regular dietary surveys that are undertaken actually look at commensality, venue or eating alone $[13,16,17]$. Considering how often a stressful working life hinders commensality at the work place or at home, it is also important to assess time and place for working meals, which we decided to address in a separate paper.

The identified qualitative studies showed that the notion of commensality to a great deal had raised interest among researchers studying meals as a central part of health or wellbeing [23-28,31,33,36,37,39,41,45,50,54,55,65,67]. Meal studies are an important part of the analysis of food and eating [74,75], as meals contribute to social life as well as impact individual behavior $[8,76]$. This was shown by the identification of different norms regarding how certain meals ought to be shared and eaten together, using different qualitative research approaches. We identified suggestions for longitudinal study designs for cohorts over an extended period of time, in order to provide a higher degree of understanding of, for example routinization of eating behavior in regards to commensality. Furthermore, to reach a broader understanding of commensality as such over research boundaries and an increased comparability of studies, a need was identified to find ways to agree on how to interpret research findings, and make them compatible especially between qualitative and quantitative methodology, as suggested by Malterud [9]. This by applying terms such as reflexivity and transferability applicable for both qualitative and quantitative methodology. This would also gain further possibility for inter/multidisciplinary studies, improving our understanding of commensal meals for wellbeing as well as in cultural/social studies. As in Phull et al. [45], discussing that economic, time and social pressures may inhibit pleasurable family dining, we see an importance of combining qualitative results with quantitative "dependent variables" for further investigating the relations between healthy and pleasurable eating patterns, as suggested by Scander [77], as a gap between "good taste" and "good health" were identified. This was partly observed by interdisciplinary studies between Nutrition, Sociology and Culinary Arts and Meal Science, using both quantitative and qualitative methodology.

We could not identify any particular differences in assessment methods between western and eastern studies. Differences in methodology between studies of elderly and the general population could not be established.

\section{Strengths and Limitations and Suggestions for Future Research}

This scoping review used only one database (Web of Science Core Collection) and did not include other search terms than commensality. It could certainly have been made more comprehensive by using other search terms such as eating together, family meal, or other terms and using several databases. The concept of commensality seemed to have been more used over time, especially during the last five years. This could also mean that we missed some early studies performed with a different choice of words for commensal eating, such as "family meals," "eating together," or "social eating". A full systematic review should include more complete search terms and other databases $[10,11]$. However, it seems clear from previous systematic reviews that the definitions for these terms are often vague [2] and that the area of research is not sufficiently studied to be able to identify and disentangle relationships between eating together and metabolic indices of health [3]. We found it important to further explore aspects of timing when eating took place, why we extracted a small number of papers that concentrated on this topic and wrote a more in-depth paper on timing.

The strengths were that the high-quality database Web of Science Core Collection was used, which only includes papers published in peer-reviewed journals. The results of the search were of a magnitude that made it possible to review in a relatively rapid manner and the papers identified represented widely different disciplines. We wanted to highlight the multidisciplinary character of commensality and the included papers point 
at the developing field of commensality research, with commonalities and diversities in research methods. Using a quick and easy method of a scoping review provided us with a good overview of the papers using the specific term "commensality," as a part of a project collection on diet, nutrition, and health with a focus on eating together [78]. Learning from each other on how to perform high-quality research on commensality has become even more important in this era of COVID-19, when commensality is challenged.

\section{Conclusions}

We conclude that in order to gather information on the importance of commensality for health and wellbeing, we should combine valid dietary survey methodology with valid estimates of commensality. Adding simple questions on where and with whom should be easy to integrate to large-scale dietary surveys. For all studies of commensality, a mix of qualitative and quantitative methods is recommended. Use of the term commensality in research papers should be encouraged, as well as providing more solid definitions of commensality and other search terms of eating together.

Author Contributions: Conceptualization, H.S., A.Y. and M.L.W. Methodology, H.S. and A.Y. Formal analysis, H.S. and A.Y. Writing-original draft preparation, H.S., writing-review and editing, H.S., A.Y. and M.L.W. All authors have read and agreed to the published version of the manuscript.

Funding: The publication fee of this open access paper was funded by a generous contribution from the Centre for Integrated Research on Culture and Society (CIRCUS), Uppsala University.

Institutional Review Board Statement: The study was conducted according to the guidelines of the Declaration of Helsinki.

Informed Consent Statement: Not applicable.

Data Availability Statement: Data sharing not applicable.

Conflicts of Interest: The authors declare no conflict of interest.

\section{References}

1. Dallacker, M.; Hertwig, R.; Mata, J. The frequency of family meals and nutritional health in children: A meta-analysis. Obes. Rev. 2018, 19, 638-653. [CrossRef]

2. McCullough, M.B.; Robson, S.M.; Stark, L.J. A Review of the Structural Characteristics of Family Meals with Children in the United States. Adv. Nutr. 2016, 7, 627-640. [CrossRef]

3. Nouriyengejeh, S.; Seyedhoseini, B.; Kordestani-Moghadam, P.; Pourabbasi, A. The study of relationship between nutritional behaviors and metabolic indices: A systematic review. Adv. Biomed. Res. 2020, 9, 66. [CrossRef] [PubMed]

4. Medical Research Center. Estimated Food Diaries. Available online: https://www.measurement-toolkit.mrc.ac.uk/diet/ subjective-methods / estimated-food-diaries (accessed on 30 November 2020).

5. Centers for Disease Control and Prevention (CDC); National Center for Health Statistics (NCHS). Analytic and Reporting Guidelines: The National Health and Nutrition Examination Survey (NHANES). Available online: http://www.cdc.gov/nchs/ data/nhanes/nhanes_03_04/nhanes_analytic_guidelines_dec_2005.pdf (accessed on 16 May 2018).

6. Moraeus, L.; Lemming, E.W.; Hursti, U.-K.K.; Arnemo, M.; Sipinen, J.P.; Lindroos, A.-K. Riksmaten Adolescents 2016-17: A national dietary survey in Sweden-design, methods, and participation. Food Nutr. Res. 2018, 62. [CrossRef] [PubMed]

7. Swedish National Food Agency. Riksmaten-Vuxna 2010-11; Swedish National Food Agency: Stockholm, Sweden, 2012.

8. Fischler, C. Commensality, society and culture. Soc. Sci. Inf. 2011, 50, 528-548. [CrossRef]

9. Malterud, K. Qualitative research: Standards, challenges, and guidelines. Lancet 2001, 358, 483-488. [CrossRef]

10. Munn, Z.; Peters, M.D.; Stern, C.; Tufanaru, C.; McArthur, A.; Aromataris, E. Systematic review or scoping review? Guidance for authors when choosing between a systematic or scoping review approach. BMC Med. Res. Methodol. 2018, 18, 1-7. [CrossRef] [PubMed]

11. Arksey, H.; O'Malley, L. Scoping studies: Towards a methodological framework. Int. J. Soc. Res. Methodol. 2005, 8, 19-32. [CrossRef]

12. De Backer, C.J. Family meal traditions. Comparing reported childhood food habits to current food habits among university students. Appetite 2013, 69, 64-70. [CrossRef] [PubMed]

13. Gotthelf, S.J.; Tempestti, C.P. Breakfast, nutritional status, and socioeconomic outcome measures among primary school students from the City of Salta: A cross-sectional study. Arch. Argic. Pediatr. 2017, 115, 424-431. 
14. Guillemin, I.; Marrel, A.; Arnould, B.; Capuron, L.; Dupuy, A.; Ginon, E.; Laye, S.; Lecerf, J.-M.; Prost, M.; Rogeaux, M. How French subjects describe well-being from food and eating habits? Development, item reduction and scoring definition of the Well-Being related to Food Questionnaire (Well-BFQ@). Appetite 2016, 96, 333-346. [CrossRef] [PubMed]

15. Holm, L.; Lauridsen, D.; Lund, T.B.; Gronow, J.; Niva, M.; Makela, J. Changes in the social context and conduct of eating in four Nordic countries between 1997 and 2012. Appetite 2016, 103, 358-368. [CrossRef] [PubMed]

16. Lund, T.B.; Kjaernes, U.; Holm, L. Eating out in four Nordic countries: National patterns and social stratification. Appetite 2017, 119, 23-33. [CrossRef] [PubMed]

17. Marquis, M.; Talbot, A.; Sabourin, A.; Riopel, C. Exploring the environmental, personal and behavioural factors as determinants for university students' food behaviour. Int. J. Consum. Stud. 2019, 43, 113-122. [CrossRef]

18. Sobal, J.; Nelson, M.K. Commensal eating patterns: A community study. Appetite 2003, 41, 181-190. [CrossRef]

19. Yates, L.; Warde, A. Eating together and eating alone: Meal arrangements in British households. Br. J. Sociol. 2017, 68, 97-118. [CrossRef] [PubMed]

20. De Morais Sato, P.; Lourenço, B.H.; Trude, A.C.B.; Unsain, R.F.; Pereira, P.R.; Martins, P.A.; Scagliusi, F.B. Family meals and eating practices among mothers in Santos, Brazil: A population-based study. Appetite 2016, 103, 38-44. [CrossRef] [PubMed]

21. Guba, E.G. Criteria for assessing the trustworthiness of naturalistic inquiries. ECTJ 1981, 29, 75. [CrossRef]

22. Andersen, S.S.; Holm, L.; Baarts, C. School meal sociality or lunch pack individualism? Using an intervention study to compare the social impacts of school meals and packed lunches from home. Soc. Sci. Inf. 2015, 54, 394-416. [CrossRef]

23. Backett-Milburn, K.C.; Wills, W.J.; Roberts, M.-L.; Lawton, J. Food, eating and taste: Parents' perspectives on the making of the middle class teenager. Soc. Sci. Med. 2010, 71, 1316-1323. [CrossRef] [PubMed]

24. Bailey, A. The migrant suitcase: Food, belonging and commensality among Indian migrants in the Netherlands. Appetite 2017, 110, 51-60. [CrossRef]

25. Belon, A.P.; Nieuwendyk, L.M.; Vallianatos, H.; Nykiforuk, C.I. Perceived community environmental influences on eating behaviors: A Photovoice analysis. Soc. Sci. Med. 2016, 171, 18-29. [CrossRef] [PubMed]

26. Cho, W.; Takeda, W.; Oh, Y.; Aiba, N.; Lee, Y. Perceptions and practices of commensality and solo-eating among Korean and Japanese university students: A cross-cultural analysis. Nutr. Res. Pract. 2015, 9, 523-529. [CrossRef] [PubMed]

27. Danesi, G. A cross-cultural approach to eating together: Practices of commensality among French, German and Spanish young adults. Soc. Sci. Inf. 2018, 57, 99-120. [CrossRef]

28. Dodds, A.; Chamberlain, K. The problematic messages of nutritional discourse: A case-based critical media analysis. Appetite 2017, 108, 42-50. [CrossRef] [PubMed]

29. Fossgard, E.; Wergedahl, H.; Bjørkkjær, T.; Holthe, A. School lunch—Children's space or teachers' governmentality? A study of 11-year olds' experiences with and perceptions of packed lunches and lunch breaks in Norwegian primary schools. Int. J. Consum. Stud. 2019, 43, 218-226.

30. Giacoman, C. The dimensions and role of commensality: A theoretical model drawn from the significance of communal eating among adults in Santiago, Chile. Appetite 2016, 107, 460-470. [CrossRef] [PubMed]

31. Neely, E.; Walton, M.; Stephens, C. Building school connectedness through shared lunches. Health Educ. 2015, 115, 554-569. [CrossRef]

32. Neuman, N.; Gottzén, L.; Fjellström, C. Masculinity and the sociality of cooking in men's everyday lives. Sociol. Rev. 2017, 65, 816-831. [CrossRef]

33. Nyberg, M.; Lennernäs Wiklund, M. Impossible meals? The food and meal situation of flight attendants in Scandinavia-A qualitative interview study. Appetite 2017, 113, 162-171. [CrossRef] [PubMed]

34. Scagliusi, F.B.; Da Rocha Pereira, P.; Unsain, R.F.; De Morais Sato, P. Eating at the table, on the couch and in bed: An exploration of different locus of commensality in the discourses of Brazilian working mothers. Appetite 2016, 103, 80-86. [CrossRef] [PubMed]

35. Schänzel, H.A.; Lynch, P.A. Family perspectives on social hospitality dimensions while on holiday. Tour. Stud. 2016, 16, 133-150. [CrossRef]

36. Sidenvall, B.; Nydahl, M.; Fjellström, C. The meal as a gift-the meaning of cooking among retired women. J. Appl. Gerontol. 2000, 19, 405-423. [CrossRef]

37. Skafida, V. The family meal panacea: Exploring how different aspects of family meal occurrence, meal habits and meal enjoyment relate to young children's diets. Sociol. Health Illn. 2013, 35, 906-923. [CrossRef] [PubMed]

38. Sobal, J.; Bove, C.F.; Rauschenbach, B.S. Commensal careers at entry into marriage: Establishing commensal units and managing commensal circles. Sociol. Rev. 2002, 50, 378-397. [CrossRef]

39. Tessier, S.; Gerber, M. Comparison between Sardinia and Malta: The Mediterranean diet revisited. Appetite 2005, 45, 121-126. [CrossRef]

40. Traphagan, J.W.; Brown, L.K. Fast food and intergenerational commensality in Japan: New styles and old patterns. Ethnology 2002, 2, 119-134. [CrossRef]

41. Vesnaver, E.; Keller, H.H.; Sutherland, O.; Maitland, S.B.; Locher, J.L. Alone at the table: Food behavior and the loss of commensality in widowhood. J. Gerontol. Ser. B Psychol. Sci. Soc. Sci. 2016, 71, 1059-1069. [CrossRef] [PubMed]

42. Ahn, R.; Nelson, M.R. Observations of food consumption in a daycare setting. Young Consum. 2015, 16, 420-437. [CrossRef]

43. Benbow, H.M. Commensality and Conflict: Food, Drink and Intercultural Encounters in the Battle of Timor. J. Intercult. Stud. 2018, 39, 35-49. [CrossRef] 
44. Persson Osowski, C.; Mattsson Sydner, Y. The family meal as an ideal: Children's perceptions of foodwork and commensality in everyday life and feasts. Int. J. Consum. Stud. 2019, 43, 178-186. [CrossRef]

45. Phull, S.; Wills, W.; Dickinson, A. Is it a pleasure to eat together? Theoretical reflections on conviviality and the Mediterranean diet. Sociol. Compass 2015, 9, 977-986. [CrossRef]

46. Sabatini, F.; Da Rocha Pereira, P.; Devincenzi, M.U.; Aburad, L.; Scagliusi, F.B. Nutrition students' experiences with constructing a portfolio about food and culture. Nutr. Diet. 2016, 73, 95-102. [CrossRef]

47. Woolley, K.; Fishbach, A. A recipe for friendship: Similar food consumption promotes trust and cooperation. J. Consum. Psychol. 2017, 27, 1-10. [CrossRef]

48. Jarosz, E. Class and eating: Family meals in Britain. Appetite 2017, 116, 527-535. [CrossRef] [PubMed]

49. Kniffin, K.M.; Wansink, B.; Devine, C.M.; Sobal, J. Eating together at the firehouse: How workplace commensality relates to the performance of firefighters. Hum. Perform. 2015, 28, 281-306. [CrossRef] [PubMed]

50. Kwon, A.R.; Yoon, Y.S.; Min, K.P.; Lee, Y.K.; Jeon, J.H. Eating alone and metabolic syndrome: A population-based Korean National Health and Nutrition Examination Survey 2013-2014. Obes. Res. Clin. Pract. 2018, 12, 146-157. [CrossRef] [PubMed]

51. Paddock, J.; Warde, A.; Whillans, J. The changing meaning of eating out in three English cities 1995-2015. Appetite 2017, 119, 5-13. [CrossRef] [PubMed]

52. Bardone, E.; Kannike, A. Creating spaces of food experience: Pop-up restaurants in Estonia. Body Pers. Priv. Perspect. Cult. Other Hum. Exp. Tartu 2017, 7, 217-244.

53. Marovelli, B. Cooking and eating together in London: Food sharing initiatives as collective spaces of encounter. Geoforum 2019, 99, 190-201. [CrossRef]

54. Ares, G.; De Saldamando, L.; Giménez, A.; Deliza, R. Food and wellbeing. Towards a consumer-based approach. Appetite 2014, 74, 61-69. [CrossRef] [PubMed]

55. Boulos, C.; Salameh, P.; Barberger-Gateau, P. Social isolation and risk for malnutrition among older people. Geriatr. Gerontol. Int. 2017, 17, 286-294. [CrossRef] [PubMed]

56. Ferdous, H.S.; Ploderer, B.; Davis, H.; Vetere, F.; O’Hara, K.; Farr-Wharton, G.; Comber, R. TableTalk: Integrating personal devices and content for commensal experiences at the family dinner table. In Proceedings of the 2016 ACM International Joint Conference on Pervasive and Ubiquitous Computing, Heidelberg, Germany, 12-16 September 2016; pp. 132-143.

57. Ferdous, H.S.; Ploderer, B.; Davis, H.; Vetere, F.; O'hara, K. Commensality and the social use of technology during family mealtime. ACM Trans. Comput. Hum. Interact. 2016, 23, 1-26. [CrossRef]

58. Giacoman, C.; Leal, D.; Rivera, V. Daily rhythms of eating in Santiago, Chile. Br. Food J. 2017, 6, 1189-1601. [CrossRef]

59. Gorman-Murray, A.; Nash, C. Transformations in LGBT consumer landscapes and leisure spaces in the neoliberal city. Urban. Stud. 2017, 54, 786-805. [CrossRef]

60. Swensen, S.; Gorringe, G.; Caviness, J.; Peters, D. Leadership by design: Intentional organization development of physician leaders. J. Manag. Dev. 2016, 39, 549-570. [CrossRef]

61. Henig, D. Hospitality as Diplomacy in Post-Cosmopolitan Urban Spaces Dervish Lodges and Sofra-Diplomacy in Post-War Bosnia-Herzegovina. Camb. J. Anthropol. 2016, 34, 76-92. [CrossRef]

62. Hopkins, N.S. Family rites in Testour, Tunisia, in the 1970s. J. N. Afr. Stud. 2018, 23, 694-715. [CrossRef]

63. Lawson, J. The Gift of Cake: Baking together in performance. Perform. Res. 2018, 23, 69-73. [CrossRef]

64. Madden, E.M. Eating Ideally: Visions of Production, Consumption, Commensality, and Cleanup. Utop. Stud. 2015, 26, 1-18. [CrossRef]

65. Masson, E.; Bubendorff, S.; Fraïssé, C. Toward new forms of meal sharing? Collective habits and personal diets. Appetite 2018, 123, 108-113. [CrossRef] [PubMed]

66. O'Connor, K.; Kerner, S.; Cynthia, C.; Morten, W. (Eds.) Commensality: From Everyday Food to Feast; Bloomsbury: London, UK, 2015.

67. Pachucki, M.C.; Karter, A.J.; Adler, N.E.; Moffet, H.H.; Warton, E.M.; Schillinger, D.; O'Connell, B.H.; Laraia, B. Eating with others and meal location are differentially associated with nutrient intake by sex: The Diabetes Study of Northern California (DISTANCE). Appetite 2018, 127, 203-213. [CrossRef] [PubMed]

68. Ray, K. Street-food, class, and memories of masculinity: An exploratory essay in three acts. FoodCult. Soc. 2018, 21, 89-100. [CrossRef]

69. Rozin, P.; Fischler, C.; Shields, C.; Masson, E. Attitudes towards large numbers of choices in the food domain: A cross-cultural study of five countries in Europe and the USA. Appetite 2006, 46, 304-308. [CrossRef] [PubMed]

70. Rozin, P.; Remick, A.K.; Fischler, C. Broad themes of difference between French and Americans in attitudes to food and other life domains: Personal versus communal values, quantity versus quality, and comforts versus joys. Front. Psychol. $2011,2,177$. [CrossRef] [PubMed]

71. Soulaimani, D. Embodiment in Moroccan Arabic storytelling: Language, stance and discourse analysis. Text. Talk 2017, 37, 335-357. [CrossRef]

72. Warde, A.; Yates, L. Understanding eating events: Snacks and meal patterns in Great Britain. Food Cult. Soc. 2017, 20, 15-36. [CrossRef]

73. Yount-André, C. Empire's leftovers: Eating to integrate in secular Paris. Food Foodways 2018, 26, 124-145. [CrossRef]

74. Mäkelä, J. Meals: The social perspective. In Meals in Science and Practice; Elsevier: Amsterdam, The Netherlands, 2009; pp. 37-49. 
75. Holm, L.; Kjærnes, U.; Niva, M. Eating and Drinking in Four Nordic Countries: Recent Changes. In Handbook of Eating and Drinking. Interdisciplinary Perspectives; Springer International Publishing: Cham, Switzerland, 2020; pp. $1323-1341$.

76. Fischler, C. Food, self and identity. Inf. (Int. Soc. Sci. Counc.) 1988, 27, 275-292. [CrossRef]

77. Scander, H. Food and Beverage Combinations: Sommeliers' Perspectives and Consumer Patterns in Sweden. Ph.D. Thesis, Comprehensive Summary, Örebro University, Örebro, Sweden, 2019.

78. Yngve, A.; Neuman, N.; Haapala, I.; Scander, H. The Project Collection Food, Nutrition and Health, with a Focus on Eating Together. Int. J. Environ. Res. Public Health 2021, 18, 1572. [CrossRef] [PubMed] 